\title{
Fiscal Policy and $\mathrm{CO}_{2}$ Emissions of New Passenger Cars in the $\mathbf{E U}$
}

\author{
Reyer Gerlagh ${ }^{1}$. Inge van den Bijgaart ${ }^{1,4}$. \\ Hans Nijland ${ }^{2}$. Thomas Michielsen ${ }^{3}$
}

Accepted: 23 September 2016 / Published online: 15 November 2016

(C) The Author(s) 2016. This article is published with open access at Springerlink.com

\begin{abstract}
To what extent have national fiscal policies contributed to the decarbonisation of newly sold passenger cars? We construct a simple model that generates predictions regarding the effect of fiscal policies on average $\mathrm{CO}_{2}$ emissions of new cars, and then test the model empirically. Our empirical strategy combines a diverse series of data. First, we use a large database of vehicle-specific taxes in 15 EU countries over 2001-2010 to construct a measure for the vehicle registration and annual road tax levels, and separately, for the $\mathrm{CO}_{2}$ sensitivity of these taxes. We find that for many countries the fiscal policies have become more sensitive to $\mathrm{CO}_{2}$ emissions of new cars. We then use these constructed measures to estimate the effect of fiscal policies on the $\mathrm{CO}_{2}$ emissions of the new car fleet. The increased $\mathrm{CO}_{2}$-sensitivity of registration taxes have reduced the $\mathrm{CO}_{2}$ emission intensity of the average new car by $1.3 \%$, partly through an induced increase of the share of diesel-fuelled cars by 6.5 percentage points. Higher fuel taxes lead to the purchase of more fuel efficient cars, but higher diesel fuel taxes also decrease the share of (more fuel efficient) diesel cars; higher annual road taxes have no or an adverse effect.
\end{abstract}

Keywords Vehicle registration taxes $\cdot$ Fuel taxes $\cdot \mathrm{CO}_{2}$ emissions

JEL Classification $\mathrm{H} 30 \cdot \mathrm{L} 62 \cdot \mathrm{Q} 48 \cdot \mathrm{Q} 54 \cdot \mathrm{Q} 58 \cdot \mathrm{R} 48$

Reyer Gerlagh

r.gerlagh@uvt.nl

1 Tilburg University, Tilburg, Netherlands

2 PBL Netherlands Environmental Assessment Agency, The Hague, Netherlands

3 CPB Netherlands Bureau for Economic Policy Analysis, The Hague, Netherlands

4 University of Gothenburg, Gothenburg, Sweden 


\section{Introduction}

Transport accounts for about $23 \%$ of energy-related $\mathrm{CO}_{2}$ emissions (Sims and Schaeffer 2014), and $15 \%$ of global greenhouse gas emissions (Blanco et al. 2014). Within the EU, passenger cars represent about $12 \%$ of $\mathrm{EU} \mathrm{CO}_{2}$ emissions. ${ }^{1}$ In the European Commission launched a strategy to reduce carbon dioxide emission intensity (i.e. emissions per kilometer) for new cars sold in the European Union. Since then, the emission intensity of new sold cars has come down remarkably, especially since $2007 .{ }^{2}$ In 2011 , the strategy was updated with a proposal to reduce EU transport greenhouse gas emissions by $60 \%$, by 2050 as compared to 1990 levels (European Commission 2011b).

The strategy is based on three pillars. The first pillar targets car manufacturers, requiring them to reduce the average emissions of new cars. The associated directive, established in 2009, aims to decrease the average emissions of new sold cars to $130 \mathrm{gCO}_{2} / \mathrm{km}$ by 2015 , and $95 \mathrm{gCO}_{2} / \mathrm{km}$ by 2020 (European Parliament and Council 2009). ${ }^{3}$ The second pillar aims to ensure that the fuel-efficiency information of new passenger cars offered for sale or lease in the EU is made available to consumers to facilitate an informed choice. Labelling is the major instrument to provide information on fuel consumption and $\mathrm{CO}_{2}$ emissions of cars. Directive 1999/94/EC obliges Member States to provide this information and to transpose the directive into national laws by 18.1.2001 at the latest (European Parliament and Council 1999).

The third pillar aims to influence consumer's vehicle purchase choices by increasing taxes on fuel-inefficient cars relative to fuel-efficient cars. The three pillars are expected to reinforce each other. Increasing the tax burden on fuel-intensive cars, relative to the burden on fuelefficient cars (third pillar), and providing information (second pillar) is expected to increase the sale of fuel-efficient cars, which in turn makes it more profitable for car manufacturers to produce fuel-efficient cars (the first pillar).

Over the past years, many EU countries implemented the third strategy pillar, by greening the car taxes through either a revision of purchase taxes, company car taxes or annual road taxes. Contrary to the first and second pillar policies, car taxes, as all other taxes, are decided on a national level, and as a consequence differ across countries. In 2005, the European Commission proposed to harmonise national vehicle registration and annual road taxes (European Commission 2005), but the proposal was rejected by the member states.

Also the level of, as well as the decline in, the emission intensity of newly purchased cars greatly varies across the European countries. Take for instance petrol cars. In 2010, average emissions from new cars ranged from $130 \mathrm{gCO}_{2} / \mathrm{km}$ (Portugal) to 160 (Luxembourg). Over the period 2001-2010, the emission intensity of petrol cars fell by on average $12 \%$ across the EU15. $\mathrm{CO}_{2}$ emissions of new cars have declined most rapidly in Sweden and Denmark. There are various possible explanations for these different experiences across countries. For example, the fall in Sweden's emission intensity may be attributed to domestic policies (Huse and Lucinda 2013), or to convergence to the EU average, whereas Denmark's move from being average to becoming one of the most fuel-efficient countries might be the consequence of its aggressive car tax policies.

\footnotetext{
${ }^{1}$ See European Commission (2016).

2 See Figs. 1 and 2 in the data description. The anticipation of regulation EC/443/2009 (European Parliament and Council 2009) is a possible explanation for the downward trend after 2007.

${ }^{3}$ All data on $\mathrm{CO}_{2}$ emission/km in this study are determined according to the NEDC guidelines (New European Driving Cycle, the prescribed European test cycle).
} 
In this paper, we exploit the variation in the stringency of vehicle fiscal policies across countries and time to address the following research question: to what extent have national fiscal policies contributed to the decarbonisation of newly sold passenger cars? We construct a simple model of a representative agent to generate predictions regarding the effect of fiscal policies on average $\mathrm{CO}_{2}$ emissions of new cars. We study changes at the aggregate level and are interested in differences between countries and changes over time within countries. ${ }^{4}$ After presenting the model, we build a dataset in which we compare vehicle tax systems across 15 countries over the years 2001-2010. We use a dataset of vehicle-specific taxes, and use these data to characterize each country's tax system at year $t$. More specifically, we construct measures for the level and $\mathrm{CO}_{2}$ sensitivity of car taxes so that we can compare different tax regimes over countries and years. We differentiate taxes by petrol and diesel, so that we construct 8 variables to provide an elaborate characterization of a country's vehicle tax system for a given year. Both the construction of the multiple tax proxies and the multicountry sample mark important contributions to the empirical literature, which typically has considered a single-country single-event. ${ }^{5}$

The constructed variables are used to empirically study the effect of the fiscal treatment, especially the car purchase tax, on the fuel efficiency of newly sold cars. We identify the effect by considering dynamic differences between countries in car taxes and in emission intensities. We control for static differences between countries through country fixed effects, control for income and for common dynamic patters (e.g. EU policies) through time fixed effects. We can identify the effect of fiscal policies on car sales as some countries have consistent low purchase taxes $\left(<30 \%\right.$ of car prices) that are not very sensitive to $\mathrm{CO}_{2}$ emissions (Belgium, France, Germany, Italy, Luxembourg, Sweden, United Kingdom), while Spain has low purchase taxes but these have become substantially more $\mathrm{CO}_{2}$ sensitive over the period 2001-2010. Greece has high purchase taxes $(>30 \%)$ but these became less $\mathrm{CO}_{2}$ sensitive over the years, and the remaining countries (Austria, Denmark, Finland, Ireland, Netherlands, Portugal) have relatively high purchase taxes $(>30 \%)$, with a $\mathrm{CO}_{2}$ component that substantially increased over the years $\left[>10 € /\left(\mathrm{gCO}_{2} / \mathrm{km}\right)\right]$, though the countries differ substantially. Our empirical strategy is based on the correlation between the uneven developments in taxes and patterns in the emission intensities for these countries.

Our research has three characteristics, which, combined, make it unique and add to existing literature: first, unlike most studies, our study deals with the effects of car taxes in multiple countries, thus controlling for year-specific effects. This makes it easier to generalize our results. Second, unlike most studies, our study jointly considers three different types of carrelated taxes, i.e. registration taxes, road taxes and fuel taxes. This allows for a better insight in the effect of different components of car-related taxes. Third, we provide a method to decompose registration taxes in two parts: the first part measures the level while the second part measures the $\mathrm{CO}_{2}$-sensitivity. The decomposition allows for a richer analysis.

We find empirical evidence that fiscal vehicle policies significantly affect emission intensities of new bought cars. We find evidence that especially the $\mathrm{CO}_{2}$-sensitivity of registration taxes and the level of the fuel taxes are important determinants of the emission intensity of new cars. The diesel-petrol substitution induced by changes in the relative taxes for diesel versus petrol cars is an important factor for the average fleet's fuel efficiency. We also find higher $\mathrm{CO}_{2}$ intensities with increasing income and a clear convergence pattern between EU countries.

\footnotetext{
4 That is, the model and our econometric analysis do not provide a detailed micro foundation of consumers' decisions; see Berry et al. (1995) or van Meerkerk et al. (2014) for such an analysis.

5 See for instance Hennessy and Tol (2011), Huse and Lucinda (2013), Ciccone (2015), D'Haultfoeuille et al. (2014), Chugh and Cropper (2014).
} 


\section{Literature}

There is an emerging empirical literature on the effects of fiscal policies on the fuel-efficiency of newly sold cars. The general finding is that fiscal policies are an effective tool to influence car purchase decisions. In addition, the literature establishes that purchase taxes are more effective than annual (road) taxes, and that tax reform can cause sizable petrol-diesel substitution.

A strong example of the responsiveness of car purchases to fiscal policies is provided by D'Haultfoeuille et al. (2014). They assess the effect of the "feebate" system that existed in France in 2008 and 2009. In this system, owners of fuel efficient cars could receive a tax rebate whereas fuel inefficient car owners had to pay a fee. The precise rebate and fee thresholds showed up remarkably in the sales for different car types, with large sales increases just below and drops just above the thresholds.

The effectiveness of car taxes can depend on the subtle features of the policy adopted. For example, compared to annual taxes, vehicle acquisition taxes are more effective in directing consumers' buying decisions (Brand et al. 2013; Gallagher and Muehlegger 2011; Klier and Linn 2015; van Meerkerk et al. 2014). Consumer myopia is considered the main reason for this discrepancy. ${ }^{6}$ For fuel costs the evidence is mixed. Where Busse et al. (2013) and Allcott and Wozny (2014) find that consumers fully value the discounted future fuel costs in their purchase decisions, other research indicates that, when deciding on whether to purchase a more fuel efficient car, consumers tend to calculate the expected savings in fuel costs only for about 3 years (see Greene et al. 2005; Kilian and Sims 2006; Greene et al. 2013).

Another phenomenon identified by the literature is the policy-induced substitution between petrol and diesel cars. Diesel engines are typically more efficient than petrol engines. Hence, when Ireland differentiated its purchase and annual road taxes according to $\mathrm{CO}_{2}$ emission intensities, sales of diesel cars increased, particularly at the expense of large petrol cars (Hennessy and Tol 2011; Rogan et al. 2011; Leinert et al. 2013). In addition to contributing to a reduction in average $\mathrm{CO}_{2}$ emissions, this unanticipated shift towards diesel cars caused an increase in $\mathrm{NO}_{\mathrm{x}}$ emissions (Leinert et al. 2013). Similar effects have been found in Norway, where a vehicle acquisition tax reform caused a 23 percentage point increase in the diesel market share (Ciccone 2015).

All research discussed above analyses the effect of specific vehicle tax policies in a single country. Hence, these papers cannot control for year-specific effects and the results are not easily generalizable. Specifically, single-country estimates may conflate domestic policies with external changes, e.g. EU-wide developments such as efficiency improvements brought by the EU directive $443 / 2009$ on $\mathrm{CO}_{2}$ standards. ${ }^{7}$ In our empirical strategy, we can identify the fiscal effects as year fixed effects absorb the effects of the common policies and technological developments. That is, our empirical analysis does not consider a single-event in one country, yet studies more broadly the fiscal treatment of car purchases and ownership in relation to car emissions. There are some previous cross-country and panel-data studies on the effect of fuel prices on fuel efficiency (Burke and Nishitateno 2013; Klier and Linn 2013). The effect of the registration and road tax level on car purchases is previously studied in Ryan et al. (2009), who use a panel structure for EU countries. They conclude that vehicle taxes, notably registration taxes, are likely to have significantly contributed to reducing $\mathrm{CO}_{2}$ emission

\footnotetext{
6 Consumer myopia, also known as nearsightedness, captures the notion that boundedly rational consumers do not exploit all available information equally, and tend to give more weight to short-term costs and benefits (DellaVigna 2009).

7 For instance, Mabit (2014) argues that in Denmark, the biggest contribution to the sales of fuel-efficient cars is probably not the 2007 tax reform, but technological improvements.
} 
intensities of new passenger cars. Ryan et al. (2009) focus on the average level of registration taxes in a country. ${ }^{8}$ We take this analysis one step further by constructing measures of the $\mathrm{CO}_{2}$ sensitivity in addition to the level of registration and road taxes. This allows us to exploit differences between EU countries in the stringency and timing of $\mathrm{CO}_{2}$-related vehicle fiscal policies. An important part of our study is thus a more comprehensive characterization of the vehicle tax system that can be used to compare differences across countries and changes over time, based on a large dataset of country-year-vehicle specific prices inclusive and exclusive of taxes.

\section{Model}

We illustrate the effect of vehicle purchase taxes on the average emission intensity with a simple model. We consider two car types. A representative consumer ${ }^{9}$ maximises (expected future) utility $u$ dependent on the current purchase of cars, $q_{1}$ and $q_{2}$, and income $m$ net of purchase expenditures $x$ :

$$
\max _{q_{1}, q_{2}} u\left(q_{1}, q_{2}, m-x\right) \text { s.t. } p_{1}^{c} q_{1}+p_{2}^{c} q_{2}=x,
$$

where $p_{i}^{c}$ are costs per quantity, including registration taxes as well as future variable costs and annual taxes. The utility function satisfies the standard assumptions on continuity, differentiability, positive derivatives, and concavity. We also assume that both types are normal goods (increasing consumption with increasing income, decreasing consumption with increasing prices) and that the total budget for cars, $x$, increases in total income, $m$.

We do not model consumers' care about the environmental performance of cars as such (see Achtnicht 2012 for an analysis along those lines), but focus on the effects of government instruments geared to direct consumers' choices. We assume that the tax is fully shifted to consumers, ${ }^{10}$ so that the consumer price of cars is

$$
p_{i}^{c}=\left(1+\tau_{i}\right) p_{i}^{p},
$$

where $\tau_{i}$ is a type-specific ad valorem tax and $p_{i}^{p}$ is the producer price.

The tax $\tau_{i}$ consists of a uniform component $\varphi$ and an environmental component, where $\theta$ is a relative weight of the environmental component. The two car types have different emission intensity, say grams of $\mathrm{CO}_{2}$ per $\mathrm{km}$, which we denote by $\beta_{i}$. Without loss of generality, let $\beta_{2}>\beta_{1}$, for example because car type 2 is more spacious, has more weight, or is more fancy. The type-specific tax becomes:

$$
\tau_{i}=\varphi+\theta \beta_{i} .
$$

We are interested in the effect of changes in car taxes on the average $\mathrm{CO}_{2}$ intensity of the car fleet, which we define as

$$
B=\frac{\beta_{1} q_{1}+\beta_{2} q_{2}}{q_{1}+q_{2}}
$$

\footnotetext{
8 Note that Ryan et al. (2009) weigh the registration tax measure by vehicle sales, so that in their analysis the right-hand-side variable depends on policy outcomes. To prevent dependency of right-hand variables on policy outcomes, we construct tax measures that do not use sales for weighing; see footnote 15 .

9 We consider the aggregate level and treat the number of cars as a continuous variable.

${ }^{10}$ We abstract here from strategic pricing by car manufacturers. Though this is important as a mechanism, our results below will hold as long as the car manufacturers pass-through part of taxes. In general, ad valorem taxes may be under- or overshifted under Bertrand competition with differentiated products (Anderson et al. 2001). If car manufacturers differentiate prices between countries so as to partly compensate taxes, the effect of fiscal measures will be reduced, and our coefficients will become smaller and less significant.
} 
Policy can change the uniform component of the car tax, $\varphi$, the environmental component, $\theta$, or both. We define the average car-tax, given by

$$
T=\frac{\tau_{1} q_{1}+\tau_{2} q_{2}}{q_{1}+q_{2}}=\varphi+\theta B,
$$

so that we can study shifts in the tax structure while keeping a constant overall tax rate. It is intuitive that an increase in the weight of car-feature $\theta$, while keeping the average tax rate $T$ constant, will decrease the average emission-intensity of the cars:

Proposition 1 An increase in the weight of environmental performance in taxes, $\theta$, while keeping average total taxes $T$ constant, will decrease the average $\mathrm{CO}_{2}$ intensity $\mathrm{B}$ :

$$
\frac{d B}{d \theta}<0
$$

Proof The policy in the proposition increases the price of the relatively emission-intensive car and decreases the price of the more fuel-efficient car. The result follows immediately from the assumption that both car types are normal goods.

Thus tilting the car taxes to become more $\mathrm{CO}_{2}$-dependent will make the car fleet more $\mathrm{CO}_{2}$ efficient. The effect of an overall car tax increase is more subtle. A price increase has a similar effect as an income reduction. Car types with a high income elasticity thus tend to lose market share when taxes uniformly increase. The impact of the tax level therefore depends on the comparative income elasticity of the two car types.

Proposition 2 If the environmental tax component $\theta$ is sufficiently small, then feature $B$ decreases with an overall tax increase $\varphi$ (or equivalently an increase in $T$ ) if and only if the less fuel-efficient car type has higher income elasticity:

$$
\frac{d B}{d \varphi}<0 \Leftrightarrow \frac{\partial q_{2}}{\partial m} \frac{m}{q_{2}}>\frac{\partial q_{1}}{\partial m} \frac{m}{q_{1}} .
$$

Proof Consider $\frac{\partial q_{2}}{\partial m} \frac{m}{q_{2}}>\frac{\partial q_{1}}{\partial m} \frac{m}{q_{1}} \Leftrightarrow \frac{\partial q_{2}}{\partial x} \frac{\partial x}{\partial m} \frac{m}{q_{2}}>\frac{\partial q_{1}}{\partial x} \frac{\partial x}{\partial m} \frac{m}{q_{1}} \Leftrightarrow \frac{\partial q_{2}}{\partial x} \frac{m}{q_{2}}>\frac{\partial q_{1}}{\partial x} \frac{m}{q_{1}} \Leftrightarrow \frac{\partial q_{2}}{\partial x} \frac{x}{q_{2}}>$ $\frac{\partial q_{1}}{\partial x} \frac{x}{q_{1}}$. An increase in $\varphi$ constitutes an equiproportional increase in the prices of all cars when $\theta=0$. Since cars are a normal good (which we use in the middle equivalence), an increase in car prices decreases demand for all types. When $\theta=0$, an increase in $\varphi$ is equivalent to a decrease in the budget for cars. Because type 2 has a larger income- and budget elasticity $\left(-\frac{\partial q_{2}}{\partial \varphi} \frac{\varphi}{q_{2}}>-\frac{\partial q_{1}}{\partial \varphi} \frac{\varphi}{q_{1}}\right)$, the average $\mathrm{CO}_{2}$-intensity $B$ goes down. By continuity, the result also holds for $\theta$ sufficiently small.

The typical hypothesis asserts that demand for luxurious cars is more income-elastic. Mannering and Winston (1985) find that large and mid-size cars have a higher income elasticity on average than compact cars. A meta-analysis by Goodwin et al. (2004) finds that fuel consumption is more income-elastic than traffic volume, which is consistent with the idea that wealthier consumers buy less fuel-efficient cars. Heffetz (2011) documents larger income elasticities for more visible consumption categories for a wide array of expenditures.

Larger cars, which are also emission-intensive, tend to be more comfortable. For example, they offer more storage and lower occupant fatality rates in vehicle-to-vehicle crashesattributes that are more easily dispensable than a car's basic transportation service. The proposition predicts a decrease in the average pollution intensity if the uniform $\operatorname{tax} \varphi$ increases. Indeed, Bordley (1993) obtains higher (Hicksian) price elasticities for luxury car segments, 
which together with their higher income elasticity also corroborates Proposition 2 . The above literature is also consistent with our own finding reported in Table 6.

For high environmental taxes $\theta$ the effect may be reverted, as an increase in the uniform tax rate $\varphi$ can then represent a fall in the relative price of less fuel-efficient cars. As we will see however, the relative importance of the environmental component in total car taxes is modest in European countries, so that the proposition's condition seems to apply.

In the next section, we construct the country-tax variables. The variable construction will closely follow the decomposition in Eq. (3), where, $\theta$ and $\beta_{i}$ will respectively be the average country-year specific tax rate, and the increase in the tax rate $(\theta)$ for a given increase in car-specific $\mathrm{CO}_{2}$ emissions $\left(\beta_{i}\right)$. We then test Propositions 1 and 2 by estimating the effect of the tax system variables $\left(\varphi\right.$ and $\theta$ ) on the average $\mathrm{CO}_{2}$ intensity of newly purchased vehicles ( $B$ in Eq. 4).

\section{Data}

Here we describe the data used for the empirical analysis. The dependent variable of interest is the average $\mathrm{CO}_{2}$ intensity of newly purchased vehicles, which depends on substitution patterns between more and less fuel efficient cars, but also on common fuel efficiency improvements over all cars, which in our econometric strategy is absorbed by time fixed effects. The main explanatory variables are fuel taxes and the two coefficients used in the model in Sect. 3: the average level of registration and annual road taxes, and their $\mathrm{CO}_{2}$ sensitivity. Here, we define the vehicle registration tax as all one-off taxes paid at the time the vehicle is registered, which is usually the time of acquisition. For road taxes, we include all annual recurrent taxes of vehicle ownership. We construct these data for each country, year, and fuel type in our sample using a detailed database with vehicle registration taxes and road taxes at vehicle-country-year level.

\subsection{Data Sources}

Our first data source is a set of manufacturer price tables as supplied by the European Commission (2011a). These tables form an unbalanced panel with 11930 observations on prices and registration taxes, across 204 car types, 20 countries (15 countries up to 2005) over the years 2001-2010. Petrol cars make up about two-third of all observations. ${ }^{11}$ This source includes the retail price data per country inclusive and exclusive of the registration tax, and allows us to construct the vehicle-country-year specific registration tax. As of 2011, the European Commission no longer collects data on automobile prices. As these prices are a crucial part of our analysis, our series end in 2010. Next we construct vehicle-country-year specific road taxes using our second data source: the ACEA (2010) tax guides and the European Commission (2011a) passenger car dataset. We also take information on fuel taxes from the ACEA tax guides. Because most cars are petrol or diesel, we restrict our sample to these two fuel types. The dataset does not contain car-specific sales data. ${ }^{12}$

The dataset from Campestrini and Mock (2011) contains information on the $\mathrm{CO}_{2}$ intensity of the newly purchased diesel and petrol cars $\left(\mathrm{CO}_{2}\right.$ emissions in $\mathrm{g} / \mathrm{km}$, weighted by sales) and the shares of diesel cars (see Fig. 5 in "Appendix"). We have this information for the

\footnotetext{
11 Dvir and Strasser (2014) use the same data for an analysis of manufacturers' price dispersion on the EU car market.

12 This poses no problem for the construction of the country tax proxies, as these are based on an unweighted sample of most-sold cars.
} 


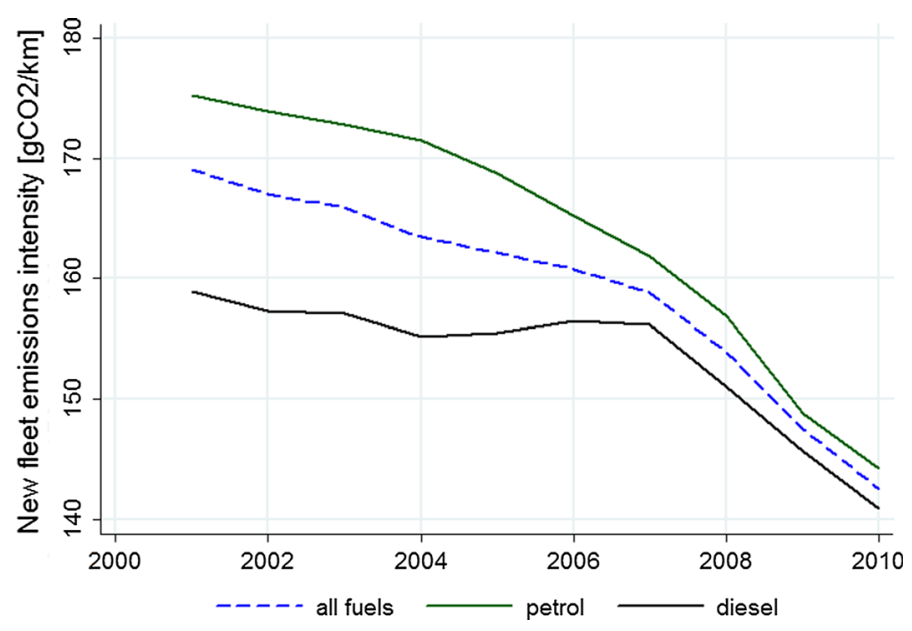

Fig. $1 \mathrm{CO}_{2}$ emission-intensity for new cars, EU15 average (the figures averages over 15 countries without weights). Source: Campestrini and Mock (2011)

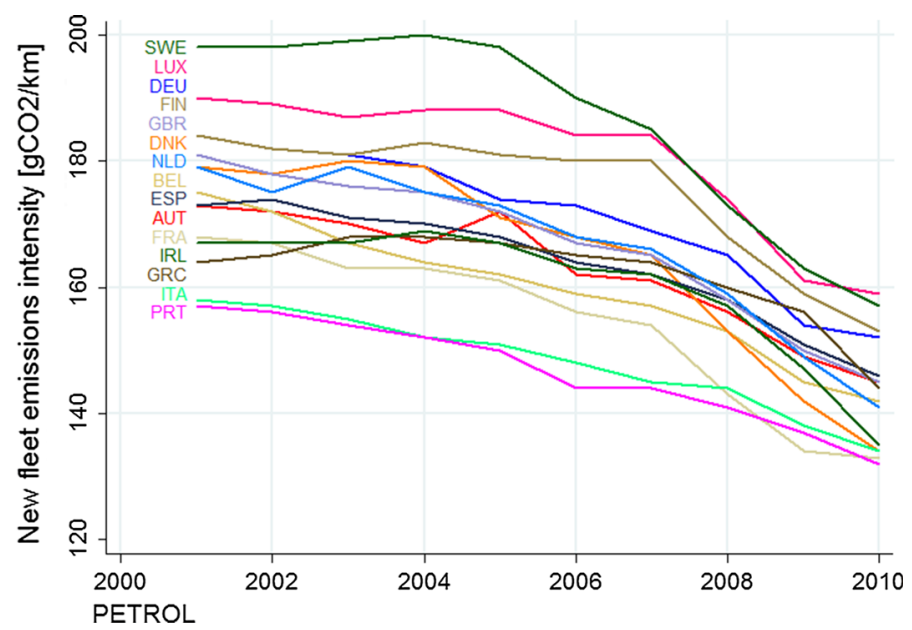

Fig. $2 \mathrm{CO}_{2}$ emission-intensity for new petrol cars, by country. Source: Campestrini and Mock (2011)

EU15 countries, from 2001 to 2010. As shown in Fig. 1, over this period, $\mathrm{CO}_{2}$ intensity has come down remarkably, albeit with sizable differences across countries (Fig. 2). Lastly, data on nominal per capita GDP is taken from Eurostat (2014). We deflate all prices (sales prices, taxes, GDP) using a common EU15 price deflator. ${ }^{13}$

\subsection{Constructing Country Average and $\mathrm{CO}_{2}$ Sensitivity of Car Taxes}

Countries have widely divergent rules for registration and road taxes. In some countries, vehicle registration taxes are based on $\mathrm{CO}_{2}$ emissions, in others, the cylindrical content is used to compute the tax, or the sales price of the car. In many instances, registration taxes

13 The deflator is constructed using a weighted average of the EU15 countries' individual inflation rates, according to standard EU methodology. See https://www.ecb.europa.eu/stats/prices/hicp/html/index.en.html. 
combine multiple variables. Rules for annual road taxes vary even more across Europe. Some countries base their annual tax on a car's engine power (in $\mathrm{kW}$ or hp), while other countries use cylinder capacity, $\mathrm{CO}_{2}$ emissions, weight and exhaust emissions. In addition to the dispersion between countries, for both registration and road taxes, many countries have changed their policies over the period 2001-2010; they adopted (temporary) discounts for fuel efficient cars, or additional charges for cars exceeding specified standards. ${ }^{14}$ We compare tax systems across countries by characterizing each country's tax system at year $t$ by the two coefficients used in our model in Sect. 3. The first coefficient describes the country-year average tax, the second the $\mathrm{CO}_{2}$ sensitivity of the tax. Both variables are computed for both the registration and road tax, and for petrol and diesel. We thus construct 8 variables that characterize a country's vehicle tax system for a given year.

We now provide the details. Let $\mathrm{CO}_{i t}$ be the $\mathrm{CO}_{2}$ intensity of car-type $i$ in year $t$, $\tau_{c i t}$ the (registration or road) (percentage) tax in country $c$, and let $\delta_{\text {cit }}$ be the index $\{0,1\}$ identifying whether the data are available for country $c$. For the sake of exposition, we do not use subscripts for fuel and tax type (registration vs. road). We construct the country-specific $\mathrm{CO}_{2}$ intensity and tax rate for the typical car offered ${ }^{15}$ on the market (denoted by bars on top over the variables):

$$
\begin{aligned}
\overline{C O 2}_{c t} & =\frac{\sum_{i} \delta_{c i t} C O 2_{i t}}{\sum_{i} \delta_{c i t}}, \\
\bar{\tau}_{c t} & =\frac{\sum_{i} \delta_{c i t} \tau_{c i t}}{\sum_{i} \delta_{c i t}} .
\end{aligned}
$$

That is, the typical car for a country has emissions $\overline{C O 2}_{c t}$ and pays a tax rate $\bar{\tau}_{c t}$. We subsequently calculate the $\mathrm{CO}_{2}$-sensitivity of the tax by comparing how much, for each country-year, the vehicle-specific tax increases for a given increase in the vehicle's $\mathrm{CO}_{2}$ emissions, on average, and weighted:

$$
\operatorname{CO} 2 T A X_{c t}=\frac{\sum_{i} w_{c i t}\left(\tau_{c i t}-\bar{\tau}_{c t}\right)}{\sum_{i} w_{c i t}\left(C O 2_{i t}-\overline{C O}_{c t}\right)},
$$

where weights are given by the deviation of the vehicle $\mathrm{CO}_{2}$ intensity from the typical $\mathrm{CO}_{2}$ intensity:

$$
w_{c i t}=\delta_{c i t}\left(C O 2_{i t}-\overline{C O 2}_{c t}\right) \text {. }
$$

The squared weights ensure that the denominator in (10) is strictly positive, and that the $\mathrm{CO}_{2}$ sensitivity is mainly determined by the tax-differences between the fuel-efficient and fuel-intensive cars.

Yet, if we want to determine a country's tax pressure and compare between countries, we should not consider the tax of the typical car for that country, but the tax for a typical car that is the same over all countries. Thus, we construct the (virtual) tax rate that would apply to a car with a $\mathrm{CO}_{2}$-emission profile $\overline{\mathrm{CO}_{t}}$ that is typical for the set of all countries:

\footnotetext{
14 van Essen et al. (2012) provides a detailed overview of the of the parameters used for the calculation of the registration and road taxes, as well as the tax for a representative vehicle, across the European countries.

15 In the construction of our tax system variables we do not weigh by sales, to prevent our description of the tax system from being contaminated by the subsequent effects of that same tax system. The tax system may of course affect sales, and thereby the $\mathrm{CO}_{2}$ emission intensity of newly purchased cars. This is discussed in Sect. 6.
} 


$$
\begin{gathered}
\overline{C O 2}=\frac{\sum_{c, i} \delta_{c i t} C O 2_{i t}}{\sum_{c, i} \delta_{c i t}}, \\
T A X_{c t}=\bar{\tau}_{c t}+C O 2 T A X_{c t}\left(\overline{C O 2}_{t}-\overline{C O 2}_{c t}\right) .
\end{gathered}
$$

The above method generates 8 variables for each country-year pair. The precise interpretation depends on the details of the input variables, $\mathrm{CO} 2{ }_{i t}$ and $\tau_{c i t}$. If $\mathrm{CO}_{2}$ emissions are measured linearly in $\left(\mathrm{gCO}_{2} / \mathrm{km}\right)$, and taxes in euros, then $\bar{\tau}_{c t}$ is the tax in euros $(€)$ paid for the car with a typical $\mathrm{CO}_{2}$-emission profile while $C O 2 T A X_{c t}$ is the increase as measured in $\left(€ /\left(\mathrm{gCO}_{2} / \mathrm{km}\right)\right)$. If taxes are measured ad valorem, then $\bar{\tau}_{c t}$ is the typical car tax rate in percentages while CO2TAX $X_{c t}$ is the increase in the tax rate per $\mathrm{gCO}_{2} / \mathrm{km}$. Our preferred specification uses the logarithm of one plus tax rates and the logarithm of $\mathrm{CO}_{2}$ emissions, so that variables are interpretable as elasticities, and (with time fixed effects) the construction is independent of price levels. In this case, a decrease of the variable $\bar{\tau}_{c t}$ of 0.01 means that the tax rate for the typical car has fallen by $1 \%$. If two car types are completely identical (including prices at the factory gate), but one car is $10 \%$ more fuel efficient, then the consumer price of the more fuel-efficient car is $0.1 \times C O 2 T A X$ per cent below the consumer price of the more fuel-intensive car. All estimations in the main text are based on the double-log variables. We have reproduced our results for a linear model, which is presented in "Linear Model" section of "Appendix". The appendix also provides the equations with more elaborate references to the details of taking logarithms.

Expressions (12) and (13) can directly be connected to Eq. (3) of the stylized model. Here, $T A X_{c t}$ resembles the country-year specific general tax rate $(\varphi)$, with $C O 2 T A X_{c t}$ the increase in the tax rate for a given increase in vehicle-specific $\mathrm{CO}_{2}$ emissions $(\theta)$.

Figure 3 below shows a typical breakdown of the vehicle registration tax rate in its level and $\mathrm{CO}_{2}$ sensitivity. The charts show the registration taxes paid in the Netherlands, in 2001 (left) and 2010 (right), for a series of petrol (upper) and diesel (lower) cars. The dots are observations for individual car types, described at the beginning of Sect. 4.1. The lines present the 'predicted' tax rates based on the two proxy variables TAX and CO2TAX constructed above. As is immediately visible from the left and right panels, the tax rate has become more sensitive to $\mathrm{CO}_{2}$ emissions between 2001 and 2010, that is, the slope of the line has increased. Figure 4 shows the decomposition of the tax in its average tax rate and the $\mathrm{CO}_{2}$ tax over the years 2000-2011. The levels of the predicted tax in the panels of Fig. 3 correspond to the values in the left panel in Fig. 4, while the slope of the predicted taxes in the panels of Fig. 3 correspond to the values in the right panel of Fig. 4. The average registration tax rate for petrol cars started at about 50 per cent, and sharply dropped in the last years reaching about 47 per cent in 2010 and 40 per cent in 2011 . The $\mathrm{CO}_{2}$ sensitivity of registration taxes however has increased substantially for both petrol and diesel cars between 2000 and 2011. Figure 4 (right panel) illustrates this shift. Various tax breaks for fuel-efficient cars came into force, which substantially increased the $\mathrm{CO}_{2}$ sensitivity of taxes, from about 10 to $25 \%$, but at the same time reduced the average tax. All other things equal, in 2011, the after-tax price decreases by about $3 \%$ if a car is $10 \%$ more fuel-efficient. The charts in Fig. 4 also show that, in the Netherlands, taxes for diesel cars are persistently above those for petrol cars; ${ }^{16}$ in our results section, we will come back to the effect of tax differentiation between petrol and diesel cars.

\footnotetext{
16 The Netherlands is atypical in the sense that registration taxes and fuel taxes are used as instruments to segregate the car market. Diesel fuel taxes are low (relative to petrol) while diesel registration taxes are high (relative to petrol). The tax scheme intends to separate long-distance drivers (who buy diesel cars) from short-distance drivers (who buy petrol cars).
} 

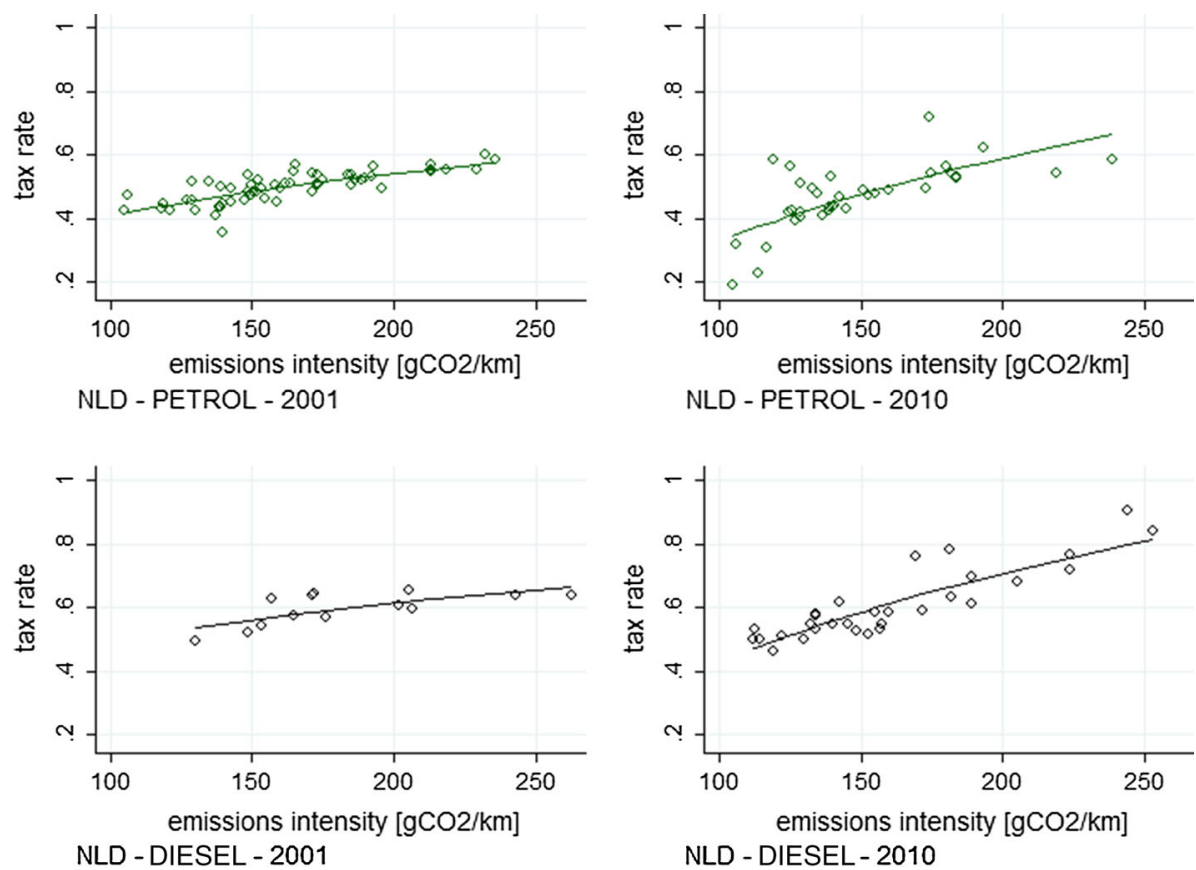

Fig. 3 Taxes per vehicle, dependent on $\mathrm{CO}_{2}$ emission intensity, for the Netherlands, 2001 (left panels) and 2010 (right panels), petrol (upper) and diesel (lower). Taxes are measured relative to car prices
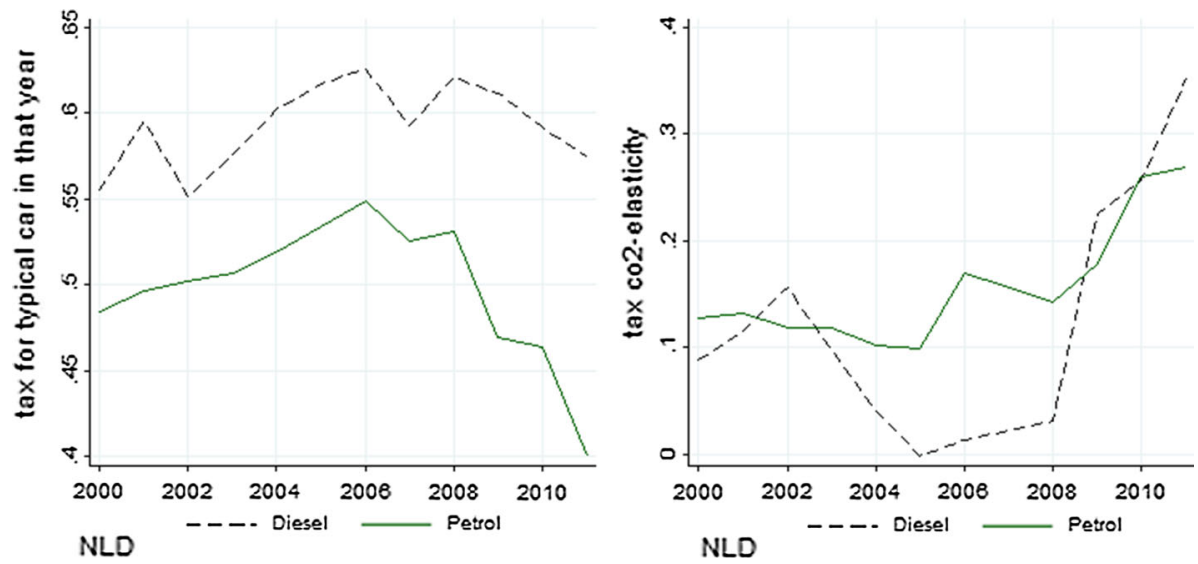

Fig. 4 Registration tax levels for typical vehicle (left), and tax dependence on $\mathrm{CO}_{2}$ emission intensity (right), for the Netherlands, 2000-2011, petrol (green solid) and diesel (black dashed). Note that the figure extends the period (2001-2010) over which we run the regressions. Also note that the y-axis on the left panel should be interpreted as 'elasticity': $\ln (1+\tau)$. Thus, a value of 0.5 implies a tax of $\exp (0.5)=65$ per cent. (Color figure online)

Table 1 provides some additional summary statistics and the means for the first and last sample years. ${ }^{17}$ Over 2001-2010, the average registration tax for diesel cars decreased from 46 to 40 per cent (see footnote at table) while for petrol cars the registration tax rate

17 Tables 13 and 14 in the "Appendix" provide a more detailed overview of the country-specific constructed registration and road taxes for the years 2001 and 2010. 
Table 1 Summary statistics for constructed tax levels and $\mathrm{CO}_{2}$ sensitivity for EU15

\begin{tabular}{|c|c|c|c|c|c|c|}
\hline & \multicolumn{4}{|c|}{$2001-2010$} & \multirow{2}{*}{$\begin{array}{l}2001 \\
\text { Mean }\end{array}$} & \multirow{2}{*}{$\begin{array}{l}2010 \\
\text { Mean }\end{array}$} \\
\hline & Mean & SD & Min & Max & & \\
\hline \multicolumn{7}{|c|}{ Vehicle registration tax rate } \\
\hline Diesel & 0.35 & 0.24 & 0.14 & 1.12 & 0.38 & 0.34 \\
\hline Petrol & 0.33 & 0.21 & 0.14 & 0.98 & 0.33 & 0.30 \\
\hline \multicolumn{7}{|c|}{ Vehicle registration tax rate, $\mathrm{CO}_{2}$ sensitivity } \\
\hline Diesel & 0.07 & 0.13 & -0.22 & 0.66 & 0.06 & 0.14 \\
\hline Petrol & 0.10 & 0.14 & -0.08 & 0.53 & 0.10 & 0.13 \\
\hline \multicolumn{7}{|c|}{ Road tax rate } \\
\hline Diesel & 0.02 & 0.02 & 0 & 0.07 & 0.02 & 0.02 \\
\hline Petrol & 0.02 & 0.01 & 0 & 0.09 & 0.02 & 0.02 \\
\hline \multicolumn{7}{|c|}{ Road tax rate, $\mathrm{CO}_{2}$ sensitivity } \\
\hline Diesel & -0.004 & 0.01 & -0.07 & 0.04 & -0.015 & 0.003 \\
\hline Petrol & -0.004 & 0.02 & -0.10 & 0.05 & -0.011 & 0.004 \\
\hline
\end{tabular}

All numbers are based on a logarithmic representation. The average tax rate for diesel cars in 2001 was thus $\exp (0.38)-1=0.46$. See Table 7 in the "Linear Model" section of "Appendix", for the tax levels and $\mathrm{CO}_{2}$ sensitivity based on the linear model

decreased from an average of 39 to $35 \%$. The extra tax paid for purchasing a high-emission vehicle has increased substantially, however. In 2001, purchasing a diesel vehicle with $10 \%$ higher emissions increased the registration tax rate by approximately 0.6 percentage point on average. By 2010, this has increased to 1.4 percentage point. For some countries, the elasticity of the registration tax rate with respect to emissions is negative. This does not directly imply that fewer taxes are paid for polluting vehicles. If a more polluting car is more expensive, then the absolute tax paid can increase while the tax rate paid can decrease. ${ }^{18}$

In 2001, the road tax rate is on average $2 \%$ of the vehicle's (tax-exclusive) purchase price, for both diesel and petrol cars. Several countries have no annual road tax. The average elasticity of the annual tax rate with respect to $\mathrm{CO}_{2}$ emissions has changed from being negative in 2001 to a positive value in 2010. Overall, there is a slight pattern towards lower road tax rates, combined with a greater dependence of the tax rate on the emissions of a car.

Vehicle fiscal measures are correlated, also when we take out country and time fixed effects. Petrol and diesel registration taxes move in tandem, both for the levels and $\mathrm{CO}_{2}$ sensitivity. The same applies to the annual taxes, where correlations exceed $80 \% .{ }^{19}$ Petrol and diesel fuel taxes are also positively correlated. The year fixed effects separate fuel price developments from fuel tax changes. There is almost no correlation between the three groups of tax instruments. For annual taxes, we see a very strong negative correlation between the level of annual taxes and its $\mathrm{CO}_{2}$ sensitivity, implying that the set of annual taxes are strongly multi-collinear, so that we must be careful when interpreting individual coefficients for annual taxes. ${ }^{20}$

\footnotetext{
18 This can happen if part of the registration tax is independent of the car price. Indeed, results from the linear model presented in the "Appendix" show that in all countries, tax levels (weakly) increase for more $\mathrm{CO}_{2}$ emission-intensive vehicles (see Table 7).

19 See Table 15 in the "Appendix" for details.

20 The negative correlation between the level of annual taxes and its $\mathrm{CO}_{2}$ sensitivity is 'natural' in the following sense. If the level of annual taxes increase, typically they increase less than proportional with the car's size, weight and price. Thus, annual taxes have a tendency to be regressive. This is picked up by a negative coefficient for the $\mathrm{CO}_{2}$ sensitivity.
} 


\section{Econometric Strategy}

The benchmark model estimates the dependence of the $\mathrm{CO}_{2}$ intensity of the new car fleet in country $c$ in year $t$ (as in Fig. 2), separately for diesel and petrol, on the two dimensions of the registration car taxes: its level and its $\mathrm{CO}_{2}$ sensitivity

$$
\text { CO2int }_{c t}=\alpha_{1 c}+\alpha_{2 t}+\beta_{1} T A X_{c t}+\beta_{2} \text { CO2TAX } X_{c t}+\sum_{k} \pi_{k} Z_{c k t}+\varepsilon_{c t},
$$

where $\alpha_{1 c}$ and $\alpha_{2 t}$ are country and time fixed effects, and the country-time specific control variables $Z$ include income and gasoline taxes. ${ }^{21,22}$ For our preferred model, we use logarithms for the dependent variable. In the linear model (see "Linear Model" section of "Appendix"), the dependent variable is measured in average grams of $\mathrm{CO}_{2}$ emissions per $\mathrm{km}$.

We add convergence patterns through the control variable, through

$$
\begin{aligned}
& Z_{c 1 t}=\text { CO2 int }_{c 0} \\
& Z_{c 2 t}=\left(\text { year }_{t}-2001\right) \times \text { CO2int }_{c 0},
\end{aligned}
$$

where $C O 2 i n t_{c 0}$ is the $\mathrm{CO}_{2}$ intensity of the new fleet in the base year 2001. Convergence between countries is measured through a negative coefficient for the interaction term (16). We assume there is no systematic correlation between observed fiscal vehicle policies and unobserved policies such as vehicle retirement plans that could induce omitted variable bias.

We first estimate the model for both fuel types jointly and separately, ${ }^{23}$ with and without the annual taxes. This allows us to assess the effect of tax levels and $\mathrm{CO}_{2}$-intensities on the emission intensity of diesel cars, petrol cars and the average fleet. We then attempt to decompose these effects into effects stemming from substitution between fuel types, effects from substitution between large and small cars, and effects from increased efficiency holding the car attributes constant. For this decomposition, we first add diesel share, average mass and average horsepower to the control variables $Z$. Next, we replace CO2int $c t$ by either of these three variables as the dependent variable in (14), leaving all other variables unchanged.

\section{Results}

\subsection{Fuel-Type Specific Effects}

Table 2 displays the results for the $\mathrm{CO}_{2}$ intensity for diesel and petrol cars respectively. Starting with the $\mathrm{CO}_{2}$ intensity of new diesel cars, we find a clear significant effect of registration taxes on $\mathrm{CO}_{2}$ emissions. Especially the $\mathrm{CO}_{2}$ sensitivity is an effective instrument to change the characteristics of newly bought vehicles: a $1 \%$ increase in $\mathrm{CO}_{2}$ sensitivity of the registration tax reduces the $\mathrm{CO}_{2}$ intensity by about $0.1 \%$ (second row Table 2). We find no significant effect for road taxes on the emissions by diesel cars. Higher diesel fuel tax

\footnotetext{
21 The fuel tax is calculated for each country-year-fuel type by fuel: $\operatorname{tax}=\ln (1+\{$ fuel tax level $\} /\{$ fuel price $\})$, where we take the fuel price as the average fuel price across the countries.

22 In "Robustness with Respect to the Economic Recession" section of "Appendix", we also check robustness for other variables to control for the economic crisis. We do not control for the effects of carmaker-specific differences in fuel efficiency improvements interacted with market share differences between countries.

23 In the latter case, we take the average and difference across fuel types for all tax variables, as opposed to the only diesel or petrol-specific ones.
} 
Table 2 Dependence of new car fleet emissions on taxes, per fuel type

\begin{tabular}{|c|c|c|c|c|}
\hline \multirow[t]{2}{*}{ Dependent variable } & \multicolumn{2}{|c|}{$(\log ) \mathrm{CO}_{2}$ intensity diesel } & \multicolumn{2}{|c|}{$(\log ) \mathrm{CO}_{2}$ intensity petrol } \\
\hline & (1) & (2) & (3) & (4) \\
\hline TAX registration & -0.021 & -0.027 & -0.031 & -0.028 \\
\hline CO2TAX registration & $-0.099 * *$ & $-0.095^{* *}$ & $-0.140 * *$ & $-0.136^{*}$ \\
\hline TAX road & 0.182 & & $1.746 * *$ & \\
\hline CO2TAX road & 0.386 & & $1.092 * *$ & \\
\hline Fuel tax rate & $-0.304 * * *$ & $-0.303 * * *$ & -0.057 & 0.004 \\
\hline$(\log )$ income & $0.251 * *$ & $0.233 * *$ & $0.193 * * *$ & $0.150 * *$ \\
\hline Convergence & $-0.051^{*}$ & $-0.048^{*}$ & $-0.028 * *$ & $-0.030 * *$ \\
\hline Time FEs & Yes & Yes & Yes & Yes \\
\hline Country FEs & Yes & Yes & Yes & Yes \\
\hline Observations & 150 & 150 & 150 & 150 \\
\hline R-squared within & 0.310 & 0.303 & 0.347 & 0.279 \\
\hline R-squared & 0.915 & 0.914 & 0.973 & 0.970 \\
\hline
\end{tabular}

Significance: $* * * p<0.01 ; * * p<0.05 ; * p<0.1$. Observations are clustered by country. The R-squared within is calculated for the residuals after both time and country FEs

rates increase the fuel efficiency of newly acquired diesel vehicles, as expected (Burke and Nishitateno 2013). In addition, we find higher $\mathrm{CO}_{2}$ intensities with increasing income and a clear convergence pattern between EU countries.

For petrol vehicles, the pattern is similar. The effect of $\mathrm{CO}_{2}$ tax sensitivity is negative and significant: the average $\mathrm{CO}_{2}$ sensitivity in $2010(0.13)$ reduces the $\mathrm{CO}_{2}$ intensity of new bought cars by about $2 \%$. An increase in the registration tax level reduces the $\mathrm{CO}_{2}$ intensity of newly acquired vehicles, but the coefficients are insignificant. For petrol vehicles, annual road taxes receive a significant coefficient, yet the signs are opposite to what is expected. ${ }^{24}$ Fuel taxes do not show a significant effect for petrol car purchases.

In our regressions, even though the annual road tax rates enter significantly, excluding them from the regression has only little effect on the coefficient for the other variables. Hence, we can interpret the other coefficients with confidence, and conclude that leaving annual taxes unaccounted for probably does not greatly alter our conclusions.

\subsection{Aggregate Effects}

Then consider the overall effect of car taxes on the new fleet emission intensity, as reported in Table 3. At first sight, it looks as if registration taxes, and specifically the $\mathrm{CO}_{2}$ sensitivity, have lost their significance as an important determinant. But this can be explained by the high collinearity between the average and difference of the $\mathrm{CO}_{2}$ sensitivity of registration taxes. ${ }^{25}$ When both the average and difference in $\mathrm{CO}_{2}$ sensitivity are included in

24 This may in part be explained by the strong negative correlation between the level and $\mathrm{CO}_{2}$ sensitivity of annual taxes (see Table 15 in the "Appendix"), which may introduce bias. In a regression where either of the annual tax measures is excluded, the coefficient on the remaining measure is greatly reduced and no longer significant.

25 After taking out time and country fixed effects, the correlation equals 0.81 . 
Table 3 Dependence of car emissions (aggregated over fuels) on taxes

Dependent variable $\quad(\log ) \mathrm{CO}_{2}$ intensity overall

(1)

TAX registration (average diesel and petrol)

TAX registration (difference diesel - petrol)

CO2TAX registration (average diesel and petrol)

CO2TAX registration (difference diesel - petrol)

TAX road (average diesel and petrol)

TAX road (difference diesel - petrol)

CO2TAX road (average diesel and petrol)

CO2TAX road (difference diesel - petrol)

Fuel tax rate (average diesel and petrol)

Fuel tax rate (difference diesel - petrol)

(log) income

Convergence

Time FEs

Country FEs

Observations

R-squared within

R-squared

TAX registration

CO2TAX registration

TAX road

CO2TAX road

Fuel tax

0.096

(2)

0.079

$0.192 * \quad 0.148$

$-0.104$

$-0.131$

0.003

$-0.005$

1.381

$1.633 *$

$0.854^{*}$

0.024

$$
-0.121^{*}
$$$$
0.127 *
$$

$0.158 * * *$

$$
-0.149
$$

0.106

$0.148 * * *$

$-0.029$

$-0.049 * *$

Yes

Yes

150

0.501

0.974

$0.050 * *$

$0.000 * * *$

0.146

0.183

0.086 *
$1.471 * *$

0.135

(3)

$0.202 * *$

$-0.131 * * *$

$-0.101$

0.076

$0.136^{* *}$ $-0.033^{*}$

Yes

Yes

150

0.458

0.971

Differences are computed as $\{$ diesel $\}-\{$ petrol $\}$. Significance: $* * * p<0.01 ; * * p<0.05 ; * p<0.1$. Observations are clustered by country. The R-squared within is calculated for the residuals after both time and country FEs. The bottom 5 rows report the $p$ values of the joint significance tests

the estimation, this collinearity causes coefficient estimates to be imprecise, and we lose significance for individual coefficients. But, the joint hypothesis that neither the average, nor the difference in the $\mathrm{CO}_{2}$ sensitivity of registration taxes has any effect is strongly rejected, at $p<0.01$ (bottom part of Table 3 ). If we only include the policy variables that we expect to have the most important effect on the overall fleet's $\mathrm{CO}_{2}$ intensity, we indeed find a strong significant effect for the average $\mathrm{CO}_{2}$ sensitivity of the registration tax (third column).

The average registration tax level does not affect overall $\mathrm{CO}_{2}$ intensity, yet higher registration taxes for diesel cars relative to petrol cars increase the average $\mathrm{CO}_{2}$ intensity of new cars. As will be further discussed in the next section, this latter effect can be explained by changes in the diesel share. For a given vehicle performance, diesel cars typically emit less $\mathrm{CO}_{2}$. Lower overall taxes for diesel cars increase the share of diesel cars and thereby decrease average overall emissions.

By subtracting the log of taxes in 2001 from those in 2010 (Table 1) and multiplying the differences with the coefficients in Table 3, we find that the changes in registration taxes 
have reduced the $\mathrm{CO}_{2}$ intensity of the new cars by $1.3 \%$ on average. ${ }^{26}$ The overall effects are modest; an explanation is that various countries with a major domestic car industry (France, Germany, Italy, United Kingdom) have relatively low registration taxes that are almost independent of emission intensities. Interestingly, based on the results in Table 2, we find that the changes in registration taxes over the period 2001-2010 have caused extant diesel drivers to choose more $\mathrm{CO}_{2}$-intensive cars on average. For these drivers, the effect of lower registration tax levels in 2010 compared to 2001 dominates the effect of the increased $\mathrm{CO}_{2}$ sensitivity.

Along the same lines, we find that higher petrol fuel taxes tend to reduce the fleet's emission intensity, while diesel fuel taxes tend to increase average emissions, though the effect is weak.

\subsection{Transmission Mechanisms}

Finally, we present an assessment of the transmission channels through which fiscal car taxes change emissions. Consumers can switch between petrol and diesel cars, in response to tax measures, but within a fuel type, they can also respond to tax measures by switching to lighter cars with less powerful engines, or alternatively, they can choose for cars with more fuel efficient engines while keeping the preferred car specifications unaffected (Fontaras and Samars 2010).

In Table 4 we present, for diesel and petrol separately, the effect of fiscal measures on the $\mathrm{CO}_{2}$ intensity with and without additional controls for diesel share, average vehicle mass and engine power. Columns 1 and 4 show the overall policy effects, conflating the changes in the fleet by those consumers that do not change fuel type, with changes brought by consumers who switch to the other fuel type. ${ }^{27}$ Columns 2 and 5 control for changes in the diesel share. Comparing column 1 versus 2 , and column 4 versus 5 , then reveals the effect consumers switching between fuels at the margin, captured by the coefficient for the diesel share. Columns 2 and 5 still conflate the policies' effects through car specifications (weight and power) with those reached through improved efficiency while keeping car weight and power constant. Controlling for these in Columns 3 and 6 then separates the efficiency effect from the effects through car specifications. We discuss the effects of fiscal measures on $\mathrm{CO}_{2}$ emissions through the diesel share and car specifications in turn. ${ }^{28}$

\subsubsection{Diesel Share}

Table 5 presents the direct effect of fiscal measures on the diesel share. As we see in this table, a higher $\mathrm{CO}_{2}$ sensitivity of registration taxes increases the share of diesel cars. Buyers who decide to acquire a diesel car as a substitute for a petrol car typically buy diesel cars that are

\footnotetext{
26 We use more decimals than shown for the numbers in Table 1, so the reader's calculation may give a slightly different result. Additional computations reveal that 0.9 percentage points of this overall effect is explained by changes in the diesel share.

27 To allow easy comparison, columns 1 and 4 in Table 4 reproduce Table 2 columns 1 and 3 respectively.

28 The transmission channels included in columns $2-4$, and 6-8 are endogenous, but the coefficient estimate does not require instruments as the endogeneity is not related to potential reverse causality.
} 


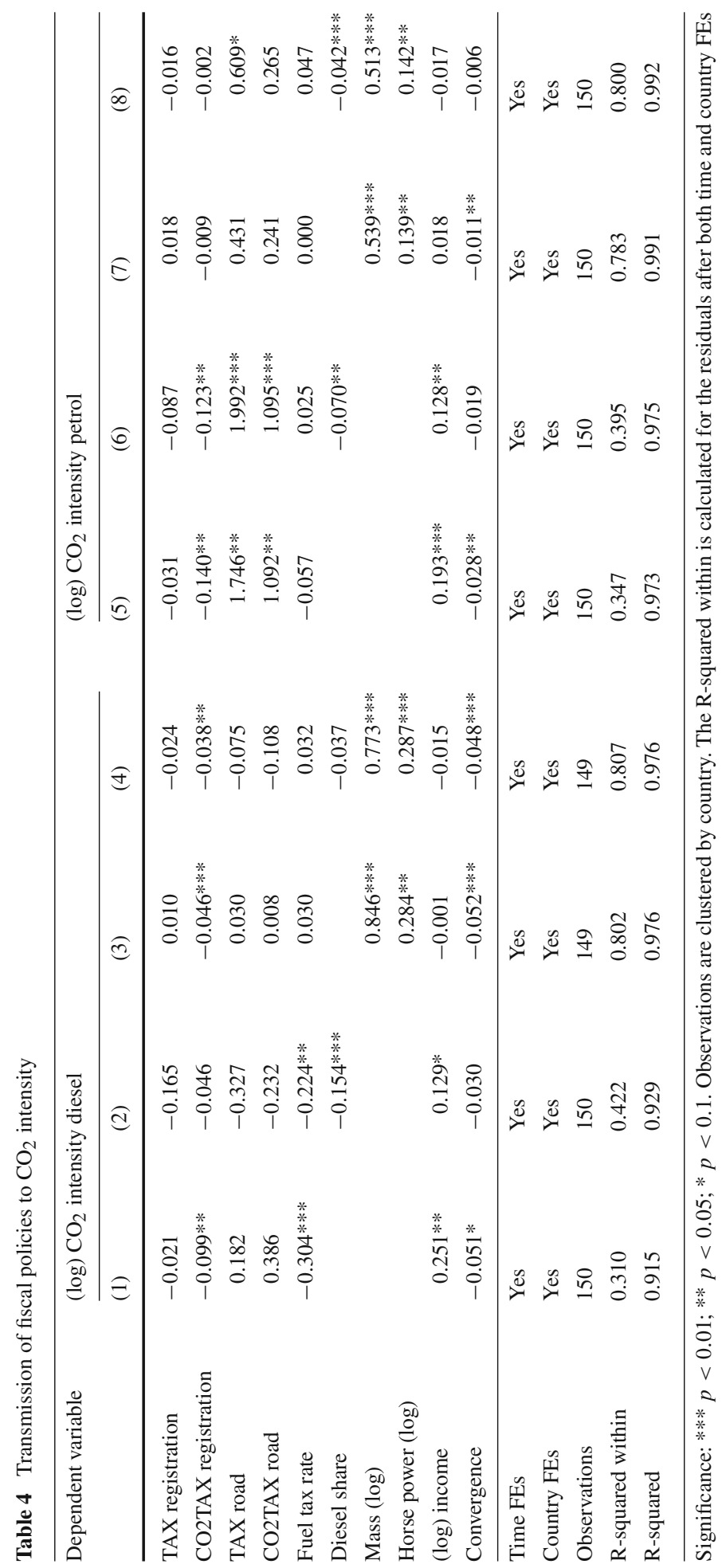


Table 5 Transmission of fiscal policies to $\mathrm{CO}_{2}$ intensity; diesel share

Dependent variable Diesel share

(1) (2) (3)

\begin{tabular}{|c|c|c|c|}
\hline TAX registration (average diesel and petrol) & $-0.978 * * *$ & $-0.815^{* *}$ & \\
\hline TAX registration (difference diesel - petrol) & -0.684 & $-0.687 *$ & $-0.876^{* *}$ \\
\hline CO2TAX registration (average diesel and petrol) & $0.348 * *$ & 0.288 & $0.496 * *$ \\
\hline CO2TAX registration (difference diesel - petrol) & 0.076 & 0.114 & \\
\hline TAX road (average diesel and petrol) & -2.226 & & \\
\hline TAX road (difference diesel - petrol) & $-13.34 * * *$ & & $-12.00 * * *$ \\
\hline CO2TAX road (average diesel and petrol) & -1.147 & & 0.112 \\
\hline CO2TAX road (difference diesel - petrol) & -0.810 & & \\
\hline Fuel tax rate (average diesel and petrol) & $0.762 * *$ & $0.904 * * *$ & $0.695 * *$ \\
\hline Fuel tax rate (difference diesel - petrol) & $-0.802 * * *$ & -0.704 & $-0.696 * * *$ \\
\hline$(\log )$ income & $-0.596 * * *$ & $-0.693 * * *$ & $-0.506^{* * *}$ \\
\hline Time FEs & Yes & Yes & Yes \\
\hline Country FEs & Yes & Yes & Yes \\
\hline Observations & 150 & 150 & 150 \\
\hline R-squared within & 0.640 & 0.333 & 0.566 \\
\hline R-squared & 0.958 & 0.923 & 0.950 \\
\hline TAX registration (joint) & $0.007 * * *$ & $0.022 * *$ & \\
\hline CO2TAX registration (joint) & $0.008 * * *$ & $0.006 * * *$ & \\
\hline TAX road (joint) & $0.010 * * *$ & & \\
\hline CO2TAX road (joint) & 0.567 & & \\
\hline Fuel tax (joint) & $0.000 * * *$ & $0.001 * * *$ & $0.005 * * *$ \\
\hline
\end{tabular}

Differences are computed as $\{$ diesel $\}-\{$ petrol $\}$. Significance: $* * * p<0.01$; $* * p<0.05 ; * p<0.1$. Observations are clustered by country. The R-squared within is calculated for the residuals after both time and country FEs. The bottom 5 rows report the $p$ values of the joint significance tests

smaller compared to the average diesel car, while they substitute away from petrol cars that are large compared to the average petrol car (see Rogan et al. 2011; Hennessy and Tol 2011; Leinert et al. 2013). This finding in the literature is supported by our Table 4; we find that the diesel share has a negative and significant coefficient in both Columns 2 and 5 (Table 4), while these coefficients become substantially smaller once we correct for the average mass and horsepower (columns 3 and 6). These consumers who substitute diesel cars for petrol cars thereby reduce the average emissions of both diesel and petrol cars. Indeed, a closer look at our data (not shown here) shows that diesel cars are on average $20 \%$ heavier compared to petrol and the average weight for both diesel and petrol cars decreases with an increase in the diesel share (see also columns 1 and 3 in Table 6). These observations jointly indicate that part of the emission reduction of new cars in the EU has likely been achieved by lower registration taxes (as observed in Table 1), which translated in an increased share of diesel cars (Table 5), which are typically more fuel efficient than petrol cars, and thus in turn decreases the $\mathrm{CO}_{2}$ intensity of the average car. In addition to the average level of registration taxes across fuels, higher registration tax levels for diesel cars compared to petrol cars tend to reduce the diesel share (see the second row in Table 5), as does a lower average $\mathrm{CO}_{2}$ sensitivity of registration 
Table 6 Transmission of fiscal policies to $\mathrm{CO}_{2}$ intensity; vehicle mass and horsepower

\begin{tabular}{|c|c|c|c|c|}
\hline \multirow[t]{3}{*}{ Dependent variable (logs) } & \multicolumn{2}{|l|}{ Diesel } & \multicolumn{2}{|l|}{ Petrol } \\
\hline & Mass & Horse power & Mass & Horse power \\
\hline & (1) & (2) & (3) & (4) \\
\hline TAX registration & -0.014 & -0.185 & -0.098 & -0.231 \\
\hline CO2TAX registration & 0.002 & -0.024 & $-0.160 * * *$ & $-0.268 * * *$ \\
\hline TAX road & -1.528 & 0.759 & $1.654 * *$ & $3.615 * *$ \\
\hline CO2TAX road & -0.696 & 0.496 & $1.073 * *$ & $1.911 * *$ \\
\hline Fuel tax rate & $-0.235^{*}$ & -0.297 & -0.030 & 0.024 \\
\hline Diesel share & $-0.086 * *$ & $-0.105 * *$ & -0.042 & -0.046 \\
\hline$(\log )$ income & $0.116^{* *}$ & 0.190 & $0.161 * *$ & $0.408 * * *$ \\
\hline Convergence & -0.003 & -0.007 & -0.014 & -0.009 \\
\hline Time FEs & Yes & Yes & Yes & Yes \\
\hline Country FEs & Yes & Yes & Yes & Yes \\
\hline Observations & 150 & 149 & 150 & 150 \\
\hline $\mathrm{R}$-squared within & 0.195 & 0.205 & 0.324 & 0.390 \\
\hline R-squared & 0.876 & 0.929 & 0.952 & 0.965 \\
\hline
\end{tabular}

Significance: $* * * p<0.01$; $* * p<0.05 ; * p<0.1$. Observations are clustered by country. The R-squared within is calculated for the residuals after both time and country FEs

taxes (third row in Table 5). For fuel taxes, we find that higher diesel (petrol) fuel taxes reduce (increase) the diesel share. Finally, higher road taxes for diesel cars reduce the diesel share..$^{29}$

\subsubsection{Mass and Horsepower}

Columns 3, 4, 7 and 8 of Table 4 confirm that emission intensities are higher when cars are larger and have more powerful engines. Table 6 presents the effect of fiscal measures on average mass and engine power. Adding mass and horse power reduces the (absolute) coefficient on registration taxes in columns 3 and 7 , and 4 and 8 of Table 4 compared to columns 1 and 5, and 2 and 6, respectively, suggesting that registration tax levels affect average mass or engine power of newly purchased vehicles. The effect is, however, statistically insignificant in Table 6, so that we evaluate the evidence as weak. We find no effect for the $\mathrm{CO}_{2}$ sensitivity of diesel registration taxes on average mass and engine power of new diesel vehicles (column 1 and 2, second row, in Table 6), but a strong significant effect for the $\mathrm{CO}_{2}$ sensitivity of petrol registration taxes. Taken together with the negative effect of the $\mathrm{CO}_{2}$ sensitivity of diesel registration taxes on diesel $\mathrm{CO}_{2}$ intensity, a possible interpretation of this finding is that higher and more $\mathrm{CO}_{2}$-sensitive diesel registration taxes push consumer purchase choices towards the technology frontier, providing the same qualities (mass and horsepower) to the consumers, at lower $\mathrm{CO}_{2}$ emissions. For petrol cars, the effects of registration taxes appear to be transmitted through the car features: higher $\left(\mathrm{CO}_{2}\right.$ sensitivity of $)$ registration taxes reduce

29 As before, the road tax level and $\mathrm{CO}_{2}$ sensitivity are strongly negatively correlated, which may bias results. Re-estimating the model excluding either the level or $\mathrm{CO}_{2}$ sensitivity of road taxes changes neither the sign nor significance of the individual effects, yet reduces the size of the effect by more than $80 \%$. 
the average mass and horse power of newly purchased vehicles, even among consumers who do not switch to diesel cars in response to the tax changes. There is less indication of a technology effect, and more evidence of switch in the type of cars bought by petrol-car consumers.

We note that the effects of income on $\mathrm{CO}_{2}$ intensities appear to be fully transmitted through car features, both for diesel and petrol cars; the effects of income on $\mathrm{CO}_{2}$ intensity in Table 5 are no longer significant when we control for mass and horsepower. Results suggest that increasing income is mainly used to increase the level of desirable features. We thus find no evidence that consumers use income increases to purchase more environmentally friendly cars. For diesel cars, the effect of diesel fuel taxes is also fully transmitted through the car features.

\section{Discussion}

We find empirical evidence that fiscal vehicle policies significantly affect emission intensities of new bought cars. A greater $\mathrm{CO}_{2}$-sensitivity of registration taxes lead to the purchase of more fuel-efficient cars. A $1 \%$ increase in the $\mathrm{CO}_{2}$ sensitivity of vehicle purchase taxes reduces the $\mathrm{CO}_{2}$ intensity of the average new vehicle by about $0.1 \%$. The changes in registration taxes from 2001 to 2010 have reduced the $\mathrm{CO}_{2}$ emission intensity of the average new car by $1.3 \%$. The diesel-petrol substitution induced by changes in the relative taxes for diesel versus petrol cars is an important factor for the average fleet's fuel efficiency. We also find higher $\mathrm{CO}_{2}$ intensities with increasing income and a clear convergence pattern between $\mathrm{EU}$ countries.

This paper is one of the first including annual road taxes, in addition to registration and fuel taxes, in the analysis of car purchase behaviour. But contrary to Ryan et al., who found that an increase in petrol circulation taxes of $10 \%$ could result in a decrease in fleet $\mathrm{CO}_{2}$ emissions of $0.3 \mathrm{~g} / \mathrm{km}$ in the short run and $1.4 \mathrm{~g}$ in the long run, we find that an increase in the annual road tax level and $\mathrm{CO}_{2}$ sensitivity increases the $\mathrm{CO}_{2}$ intensity of new petrol cars. We are not sure what causes this finding. It is not obvious that individuals account for future annual tax expenses, as discussed in Sect. 2. It is possibly because annual road taxes are not salient, but the high collinearity between annual road taxes may also play a role.

We find that higher petrol fuel taxes tend to reduce the fleet's emission intensity, while diesel fuel taxes tend to reduce average emissions for the diesel fleet but also induce substitution of petrol cars for diesel cars. The finding is consistent with Ryan et al. (2009), but a subtle and important distinction from the general conclusion in the literature that higher petrol prices tend to lead to more fuel efficient cars (Davis and Kilian 2011; Burke and Nishitateno 2013; Klier and Linn 2013).

There is a clear positive potential for fiscal instruments as part of the set of policy measures aimed at reducing $\mathrm{CO}_{2}$ emissions from cars. ${ }^{30}$ Our findings thus support the European Commission's third policy pillar. Yet, we should not overstate the contribution of registration taxes. The overall effect of the registration tax changes that we identify, a $1.3 \%$ improvement of fuel efficiency, is small compared to the overall achievement over the period observed (Fig. 1). Innovation and other policy instruments have played a substantial role. In that context, it is important to understand that various policy instruments can strengthen, but also counter each other. In the European Directive EC/443/2009 car manufacturers are evaluated (from 2015 onwards) based on their average emissions of cars sold across all EU countries.

30 See Burke (2014) for a broader discussion. 
Increased sales of fuel efficient cars in one country thus allows manufactures to sell more fuel inefficient cars in other countries. The principle, sometimes referred to as a 'waterbed-effect', implies that environmental gains from fiscal national policies can leak away as the sale of more fuel-efficient cars in a country with a fiscal regime that puts a large premium on $\mathrm{CO}_{2}$ emissions, is countered by the sale of more fuel-intensive cars in other countries. National fiscal policies, aimed at the demand side, and in line with the third pillar of EU policies, might thus be less effective conditional on the effectiveness of the first pillar of EU policy, aimed at the supply of fuel efficient cars throughout the EU. Given an exogenously set ceiling for the EU-wide $\mathrm{CO}_{2}$ emissions, there is no clear economic gain from a diversified fiscal regime between EU countries, while there are social costs (Hoen and Geilenkirchen 2006). Indeed, a few years ago, the EU proposed to harmonize vehicle taxes in the EU, but the proposal was rejected by the Member States. We also mention a few other potential disadvantages of fiscal support of fuel efficient cars.

In this paper, we focus on the average emission intensity of new cars. Reducing taxes for small, fuel-efficient cars can lead to scale effects (i.e. more cars) and intensity-of-use effects (i.e. more kilometres per car). Konishi and Meng (2014) show that in a green tax reform in Japan, this scale effect offset the composition effect (i.e. a bigger share of fuel-efficient cars) by approximately two third. In addition, there is a rebound effect. Fuel-efficient cars are cheaper to drive, and a portion of the $\mathrm{CO}_{2}$ gains by $\mathrm{CO}_{2}$-based vehicle purchase tax is lost as the fuel-efficient cars increase car travel demand (Khazzoom 1980). The existence of the effect is undisputed, but its magnitude remains an issue of debate (see e.g. Brookes 2000; Binswanger 2001; Sorrell and Dimitroupolos 2008). Frondel and Vance (2014) estimated that $44-71 \%$ of potential energy savings from efficiency improvements in Germany between 1997 and 2012 were lost due to increased driving. The rebound effect may be mitigated if part of the increase in sales of new, clean cars is due to consumers sooner retiring their less-efficient cars.

Of the policies aimed at reducing $\mathrm{CO}_{2}$ emissions, excise fuel duties most directly target the environmental objective, specifically since the use of the car is accountable for about $80 \%$ of $\mathrm{CO}_{2}$ emissions in its life-cycle (Gbegbaje-Das 2013). Fuel excise duties are also closer to the 'polluter pays-principle', one of the leading principles of European Environmental Policy (European Parliament and Council 2004). Taxing fuels would lead to more efficient cars and lower mileage without rebound effects (Chugh and Cropper 2014), making it the preferred instrument for reducing road transport emissions. Yet significant fuel tax increases are politically costly.

There are also secondary effects of fiscal policies. When consumers choose lighter cars that are more fuel efficient, not only $\mathrm{CO}_{2}$ emissions fall but emissions of $\mathrm{NO}_{\mathrm{x}}$ and $\mathrm{PM}_{10}$ as well. A weight reduction of $10 \%$ results in a decrease of the emission of $\mathrm{NO}_{\mathrm{x}}$ with $3-4 \% \mathrm{NO}_{\mathrm{x}}$ (Nijland et al. 2012). On the other hand, substituting diesel cars for petrol cars improves $\mathrm{CO}_{2}$ fuel efficiency by about 10-20\%, yet increases the emissions of $\mathrm{NO}_{\mathrm{x}}$ (Nijland et al. 2012). In the case of $\mathrm{PM}_{10}$ the situation is not clear, as modern petrol cars with direct injection might emit more $\mathrm{PM}_{10}$ than modern diesel cars (Köhler 2013). Lighter cars also reduce fatalities for drivers of other vehicles, pedestrians, bicyclists, and motorcyclists (Gayer 2004; White 2004). The design of the fiscal regime, encouraging lighter cars or encouraging diesel cars, can alter the secondary effects substantially.

We used $\mathrm{CO}_{2}$ emission data according to the NEDC guidelines. It is known that the tests typically report lower emissions compared to realistic conditions, especially for cars that score very well at the tests (Ligterink and Bos 2010; Ligterink and Eijk 2014). Moreover, the gap between test results and realistic estimates for normal use have increased over time; from about $8 \%$ in 2001 to $21 \%$ in 2011, with a particularly strong increase since 2007 (Mock et al. 
2012, 2014). The gap between test values and estimates of realistic use values also affects the estimated emission of air pollutants, particularly the emissions of NOx from diesel cars (e.g. Hausberger 2006; Vonk and Verbeek 2010). To continue the use of test-cycles therefore requires an update of procedures and improvement of their reliability as predictor of real-life use.

Finally, we mention three limitations of our study. We proxy the fiscal treatment of personal vehicles, assuming that taxes change continuously with $\mathrm{CO}_{2}$ emissions. Yet, there are indications that consumers are more sensitive to discrete price increases, such as tax breaks for cars that meet specific criteria (see e.g. Finkelstein 2009; Klier and Linn 2015; Kok 2013). This study did not explicitly model these elements of tax design. Second, about half of the new sales in Europe are company cars (Copenhagen Economics 2010). One of the reasons for their widespread use is their beneficial tax treatment (Gutierrez-i-Puigarnau and van Ommeren 2011), including implicit subsidies as employees often do not bear the variable costs of private use (Copenhagen Economics 2010). Therefore, private consumers and business consumers react differently to price signals such as fiscal rules and fuel taxes. We do not have available data on the two separate markets and must leave this topic to future research. Third, we did not consider other fiscal measures such as the scrap subsidies which had major effects on sales in various countries, though the effects on the fuel efficiency is considered limited (Grigolon et al. 2016).

Acknowledgments We received a remarkable amount of constructive and helpful comments. The authors wish to thank the anonymous referees, and also Alice Ciccone, Anco Hoen, Anna Alberini, Christian Huse, Davide Cerruti, Georgios Fontaras, Gerben Geilenkirchen, Herman Vollebergh, Ingmar Schumacher, Joshua Linn, Justin Dijk, Lutz Kilian, Martin Achtnicht, Robin Stitzing, Robert Kok, Stephan Leinert, Theo Zachariadis. All remaining errors are ours. We are grateful for the financial support from the Netherlands Environmental Assessment Agency (PBL) and the Norwegian Research Council (through CREE). We thank Ben Medendorp for converting data from pdf into Excel.

Open Access This article is distributed under the terms of the Creative Commons Attribution 4.0 International License (http://creativecommons.org/licenses/by/4.0/), which permits unrestricted use, distribution, and reproduction in any medium, provided you give appropriate credit to the original author(s) and the source, provide a link to the Creative Commons license, and indicate if changes were made.

\section{Appendix}

\section{Loglinear Detailed Model of Sect. 4.2}

We construct the country-car-year variables $L O G C O 2_{i t}=\ln \left(C O 2_{i t}\right)$ and $L O G T A X_{c i t}=$ $\ln \left(1+\tau_{c i t}\right)$ from our database, and subsequently construct the country averages [Eqs. (8), (9)], denoted by a bar over the variables:

$$
\begin{aligned}
\overline{\operatorname{LOGCO2}}_{c t} & =\frac{\sum_{i} \delta_{c i t} L O G C O 2_{i t}}{\sum_{i} \delta_{c i t}} \\
\overline{\operatorname{LOGTAX}}_{c t} & =\frac{\sum_{i} \delta_{c i t} L O G T A X_{c i t}}{\sum_{i} \delta_{c i t}}
\end{aligned}
$$

We subsequently calculate the $\mathrm{CO}_{2}$ sensitivity of the tax (10), LOGCO2TAX how much taxes increase when $\mathrm{CO}_{2}$ emissions increase, on average, and weighted:

$$
\operatorname{LOGCO} 2 T A X_{c t}=\frac{\sum_{i} w_{c i t}\left(\operatorname{LOGTAX}_{c i t}-\overline{\operatorname{LOGTAX}}_{c t}\right)}{\sum_{i} w_{c i t}\left(\operatorname{LOGCO}_{i t}-\overline{\operatorname{LOGCO2}}_{c t}\right)}
$$


where weights are given by the deviation from the average $\mathrm{CO}_{2}$ intensity (11):

$$
w_{c i t}=\delta_{c i t}\left(L O G C O 2_{i t}-\overline{L O G C O 2}_{c t}\right)
$$

We then construct the (virtual) tax rate $L O G T A X_{c t}$ that would apply to a car with a $\mathrm{CO}_{2}$ emission profile that is typical for the aggregate of all countries ((12) and (13)):

$$
\begin{gathered}
\overline{\operatorname{LOGCO}}_{t}=\frac{\sum_{c, i} \delta_{c i t} L O G C O 2_{i t}}{\sum_{c, i} \delta_{c i t}} \\
\operatorname{LOGTAX}_{c t}=\overline{\operatorname{LOGTAX}}_{c t}+\operatorname{LOGCO2TAX}_{c t}\left(\overline{\operatorname{LOGCO} 2}_{t}-\overline{\operatorname{LOGCO2}}_{c t}\right)
\end{gathered}
$$

The two constructed variables LOGTAX $X_{c t}$ and LOGCO2TAX $X_{c t}$, are used as independent variables explaining the average emission intensity of the new car fleet (14). Note that the country-average $\mathrm{CO}_{2}$ intensity constructed in (8) or (17) is not the same variable used in the econometric regression, used as independent variable in Sect. 5 (14). The country-average $\mathrm{CO}_{2}$ intensity in (8) or (17) is measured only for those car types for which we have price and tax data, and its purpose is solely to construct the $\mathrm{CO}_{2}$ sensitivity of car taxes in (10) or (19). The country-average $\mathrm{CO}_{2}$ intensity used in Sect. 5 (14) is from an independent source, and is based on all car sales in a country-year; it is the independent variable that we explain using the country tax variables constructed in Sect. 4.2.

\section{Linear Model}

In the main text, we characterized a country's tax system by two coefficients: the average rate, and its $\mathrm{CO}_{2}$ sensitivity, which is defined as elasticity of the tax rate with respect to $\mathrm{CO}_{2}$ emissions. In this appendix, we take a linear approach. Here, the $\mathrm{CO}_{2}$ sensitivity is instead defined as the increase in the tax level for a given increase in $\mathrm{CO}_{2}$ emissions (in grams per $\mathrm{km})$. To decompose the tax in these elements, we estimate

$$
\tau_{c i t}=T A X_{c t} p_{c i t}^{p}+C O 2 T A X_{c t}\left(\mathrm{CO}_{i t}-\overline{C O 2}{ }_{t}\right)
$$

where $\tau_{c i t}$ is the tax paid (in euro's) for vehicle $i$ in country $c$ at time $t, p_{c i t}^{p}$ is the tax exclusive purchase price, $C O 2_{i t}$ the vehicle $\mathrm{CO}_{2}$ emission in $\mathrm{g} / \mathrm{km}$ and $\overline{\mathrm{CO} 2}$ the average time $t \mathrm{CO}_{2}$ emissions in $\mathrm{g} / \mathrm{km}$. We then characterize a tax system by $T A X_{c t}$, which is the average tax rate as a percentage of the purchase price, and CO2TAX $X_{c t}$ which is the additional tax, in euro's, per $\mathrm{g} / \mathrm{km}$ additional $\mathrm{CO}_{2}$ emissions. ${ }^{31}$

Table 7 presents the summary statistics equivalent to Table 1, as the numbers in this table are potentially easier to interpret. Consistent with the results for the logarithmic model, we find that from 2001 to 2010, the average registration taxes have fallen, yet its $\mathrm{CO}_{2}$ sensitivity has increased, for petrol and diesel cars. For example, for diesel cars, the average registration tax fell from $53 \%$ in 2001 to $44 \%$ in 2010. In 2001 however, emitting an additional 10 $\mathrm{gCO}_{2} / \mathrm{km}$ would increase the tax by 88 euros on average. In 2010, this has increased to 382 euros. Adjusting the decomposition slightly alters the estimation of the average tax rate. In Table 1, the 2001 (2010) diesel registration tax rate is 46 (40)\%, for petrol this is 39 (34) \%; in Table 7 these rates are approximately 7 percentage points higher.

With this decomposition, we consider the effect of the vehicle registration tax rate, and the $\mathrm{CO}_{2}$ sensitivity of the tax paid on the average $\mathrm{CO}_{2}$ intensity of newly purchased vehicles.

31 Note that this simultaneous estimation of $T A X_{c t}$ and CO2TAX $X_{c t}$ is not a departure from the decomposition strategy in Sect. 4.2, as the decomposition in the main text is equivalent to estimating $\tau_{c i t}=T_{A X}+$ $C O 2 T A X_{c t}\left(\mathrm{CO}_{i t}-\overline{\mathrm{CO}_{t}}\right)$, with all variables as defined in Sect. 4.2. 
Table 7 Summary statistics for constructed coefficients for EU15-linear model

\begin{tabular}{|c|c|c|c|c|c|c|}
\hline & \multicolumn{4}{|c|}{$2001-2010$} & \multirow{2}{*}{$\begin{array}{l}2001 \\
\text { Mean }\end{array}$} & \multirow{2}{*}{$\begin{array}{l}2010 \\
\text { Mean }\end{array}$} \\
\hline & Mean & $\mathrm{SD}$ & Min & Max & & \\
\hline \multicolumn{7}{|c|}{ Vehicle registration tax rate } \\
\hline Diesel & 0.48 & 0.45 & 0.15 & 2.23 & 0.53 & 0.44 \\
\hline Petrol & 0.47 & 0.45 & 0.15 & 2.09 & 0.46 & 0.42 \\
\hline \multicolumn{7}{|c|}{ Vehicle registration tax, $\mathrm{CO}_{2}$ sensitivity } \\
\hline Diesel & 17.4 & 33.10 & -76.67 & 151.80 & 8.8 & 38.2 \\
\hline Petrol & 23.2 & 39.73 & -9.56 & 189.08 & 20.5 & 32.3 \\
\hline \multicolumn{7}{|c|}{ Road tax rate } \\
\hline Diesel & 0.02 & 0.01 & 0 & 0.06 & 0.02 & 0.02 \\
\hline Petrol & 0.01 & 0.01 & 0 & 0.07 & 0.02 & 0.01 \\
\hline \multicolumn{7}{|c|}{ Road tax, $\mathrm{CO}_{2}$ sensitivity } \\
\hline Diesel & -0.49 & 2.01 & -9.08 & 7.99 & -1.38 & 0.28 \\
\hline Petrol & -0.84 & 2.28 & -12.27 & 5.71 & -1.48 & -0.02 \\
\hline
\end{tabular}

Tax rates are measured as percentage of the tax exclusive purchase price, $\mathrm{CO}_{2}$ sensitivity in euro per $\mathrm{gCO} / \mathrm{km}$ For this table, data are not weighted

Table 8 Dependence of new car fleet emissions on taxes, per fuel type, linear model

\begin{tabular}{|c|c|c|c|c|c|c|}
\hline \multirow[t]{2}{*}{ Dependent variable } & \multicolumn{3}{|c|}{$\mathrm{CO}_{2}$ intensity diesel } & \multicolumn{3}{|c|}{$\mathrm{CO}_{2}$ intensity petrol } \\
\hline & (1) & (2) & (3) & (4) & (5) & (6) \\
\hline TAX registration & -7.982 & -6.329 & $-22.51 * * *$ & 2.892 & 2.620 & 0.257 \\
\hline CO2TAX registration & -0.032 & -0.033 & -0.005 & -0.072 & $-0.079 *$ & -0.052 \\
\hline TAX road & 102.55 & & 73.20 & 127.5 & & 207.7 \\
\hline CO2TAX road & -0.095 & & -0.260 & 0.553 & & 0.683 \\
\hline Fuel tax rate & $-35.50 * *$ & $-36.71 * *$ & -18.71 & -5.705 & -2.812 & 0.692 \\
\hline Diesel share & & & $-30.07 * * *$ & & & $-9.874 *$ \\
\hline$(\log )$ income & $36.79 * *$ & $38.64 * *$ & 11.67 & $29.45 * * *$ & $25.92 * * *$ & $21.42 * *$ \\
\hline Convergence & -0.042 & -0.045 & -0.014 & $-0.047 * * *$ & $-0.049 * * *$ & $-0.039 * * *$ \\
\hline Time FEs & Yes & Yes & Yes & Yes & Yes & Yes \\
\hline Country FEs & Yes & Yes & Yes & Yes & Yes & Yes \\
\hline Observations & 150 & 150 & 150 & 150 & 150 & 150 \\
\hline R-squared within & 0.295 & 0.289 & 0.472 & 0.406 & 0.392 & 0.437 \\
\hline $\mathrm{R}$-squared & 0.909 & 0.908 & 0.932 & 0.974 & 0.973 & 0.975 \\
\hline
\end{tabular}

Significance: $* * * p<0.01$; ** $p<0.05 ; * p<0.1$. Observations are clustered by country. The R-squared within is calculated for the residuals after both time and country FEs

Results are presented in Tables 8 and 9, where the former table also includes results for the diesel share as a transmission mechanism. Since we now take the level of the additional tax on $\mathrm{CO}_{2}$ emissions, and the level of the average $\mathrm{CO}_{2}$ intensity of newly purchased vehicles interpretation is slightly different compared to Tables 2 and 3. Take for example the first column of Table 8 . Here, a 10 percentage point increase in the vehicle registration tax rate is expected to reduce the $\mathrm{CO}_{2}$ intensity of diesel cars by $0.8 \mathrm{gCO}_{2} / \mathrm{km}$. Similarly, the coefficient 


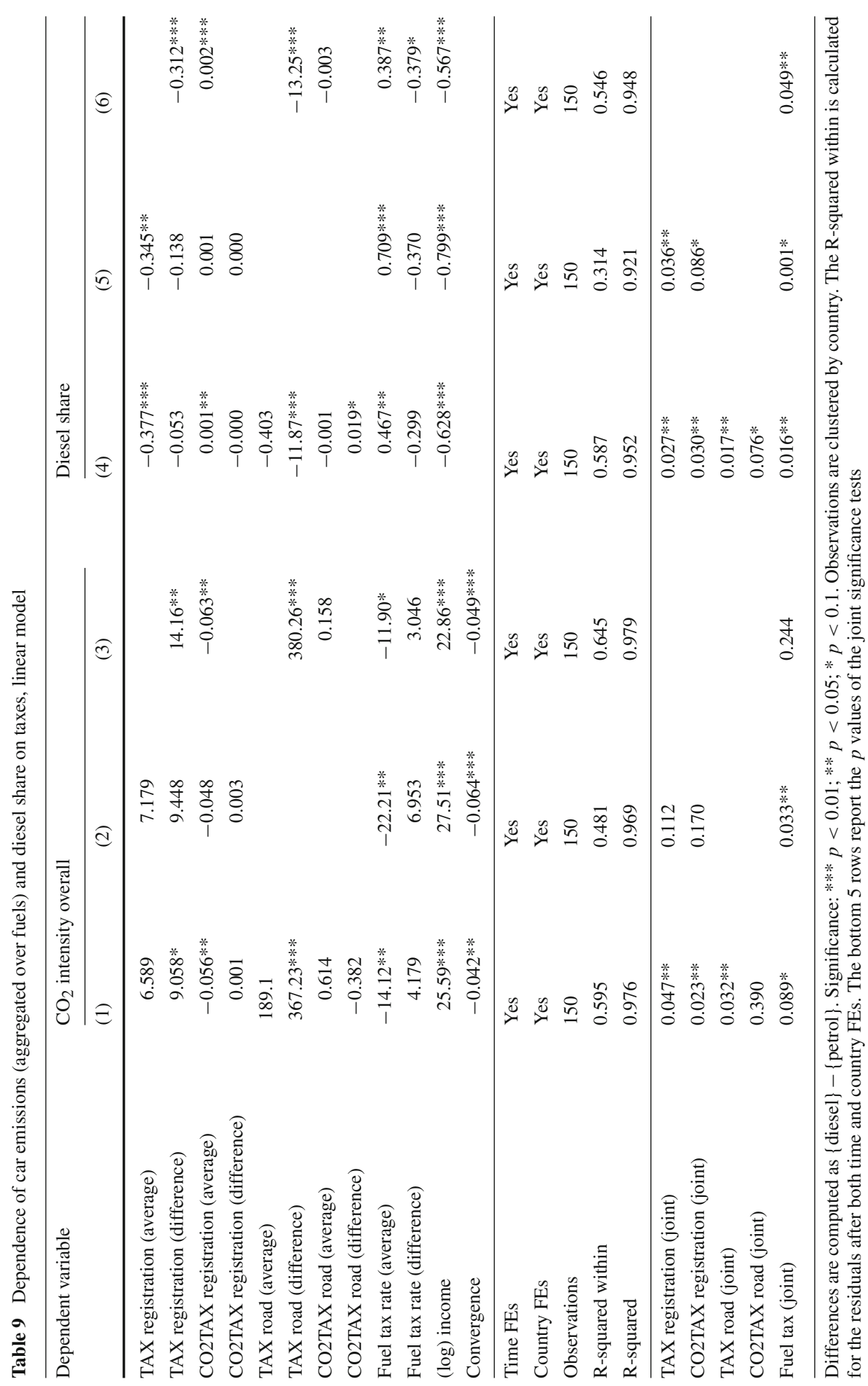


Table 10 Summary statistics for constructed tax levels and $\mathrm{CO}_{2}$ sensitivity for EU15-pooled

\begin{tabular}{|c|c|c|c|c|c|c|}
\hline & \multicolumn{2}{|c|}{ 2001-2010 } & \multicolumn{2}{|l|}{2001} & \multicolumn{2}{|l|}{2010} \\
\hline & Mean & SD & Min & Max & Mean & Mean \\
\hline Vehicle registration tax rate & 0.34 & 0.22 & 0.14 & 1.04 & 0.34 & 0.32 \\
\hline Vehicle registration tax rate, $\mathrm{CO}_{2}$ sensitivity & 0.09 & 0.13 & -0.05 & 0.50 & 0.10 & 0.14 \\
\hline Road tax rate & 0.02 & 0.01 & 0 & 0.08 & 0.02 & 0.02 \\
\hline Road tax rate, $\mathrm{CO}_{2}$ sensitivity & -0.004 & 0.02 & -0.09 & 0.04 & -0.01 & 0.005 \\
\hline
\end{tabular}

* Tax rates are measured as percentage of the tax exclusive purchase price, $\mathrm{CO}_{2}$ sensitivity in euro per $\mathrm{gCO}_{2} / \mathrm{km}$. Note: For this table, data are not weighted

Table 11 Dependence of car emissions (aggregated over fuels) and diesel share on taxes_-pooled

\begin{tabular}{|c|c|c|c|c|}
\hline \multirow[t]{2}{*}{ Dependent variable } & \multicolumn{2}{|c|}{$\mathrm{CO}_{2}$ intensity overall } & \multicolumn{2}{|l|}{ Diesel share } \\
\hline & (1) & (2) & (5) & (6) \\
\hline TAX registration & 0.031 & 0.036 & -0.896 & $-0.821 *$ \\
\hline CO2TAX registration & $-0.102 *$ & $-0.088^{*}$ & 0.283 & 0.245 \\
\hline TAX road & 0.610 & & -0.714 & \\
\hline CO2TAX road & 0.611 & & -2.317 & \\
\hline Fuel tax rate (average) & $-0.171^{* *}$ & $-0.157^{*}$ & $0.992 * * *$ & $0.936^{* * *}$ \\
\hline Fuel tax rate (difference) & 0.108 & 0.101 & -0.632 & -0.677 \\
\hline$(\log )$ income & $0.177 * * *$ & $0.157 * *$ & $-0.859 * * *$ & $-0.736^{* * *}$ \\
\hline Convergence & $-0.051 * * *$ & $-0.052 * *$ & & \\
\hline Time FEs & Yes & Yes & Yes & Yes \\
\hline Country FEs & Yes & Yes & Yes & Yes \\
\hline Observations & 150 & 150 & 150 & 150 \\
\hline R-squared within & 0.387 & 0.359 & 0.365 & 0.299 \\
\hline $\mathrm{R}$-squared & 0.968 & 0.966 & 0.927 & 0.919 \\
\hline
\end{tabular}

Significance: $* * * p<0.01$; ** $p<0.05 ; * p<0.1$. Observations are clustered by country. The R-squared within is calculated for the residuals after both time and country FEs

of -0.032 on $\mathrm{CO} 2 \mathrm{TAX}$ registration implies that a 10 euro increase in the effective registration tax rate on $\mathrm{CO}_{2}$ emissions for diesel cars, is expected to reduce the average $\mathrm{CO}_{2}$ intensity of diesel cars by $0.32 \mathrm{gCO}_{2} / \mathrm{km}$. The sign of coefficients is in line with the logarithmic model, but we lose many significant coefficients, indicating that the logarithmic model provides more precise estimates.

\section{Pooled Model}

In the main text, we distinguish between taxes paid on diesel and petrol vehicles. This is motivated by a clear difference in the taxes levied across the two fuel types (see Tables 1 , 13, 14), as well as the large shift in diesel shares and the fact that it seems to be driven by differences in tax treatment. However, as Table 15 shows, tax rates paid for diesel and petrol vehicles are strongly correlated, inflating standard errors of the individual regressors. 
To address this issue, we have estimated a 'pooled' model. For this estimation, the tax variables are no longer constructed for each fuel types, but rather generally, across fuel types. Table 10 below reproduces Table 1 for the pooled setup. The constructed tax levels and $\mathrm{CO}_{2}$ sensitivities lie approximately in between those for the fuel type-specific ones. Table 11 then shows our estimation results. Estimations are both qualitatively and quantitatively in line with the results of Table 3, where the pooled model seems to capture mostly the estimated effect of the average level of either TAX or CO2TAX in Table 3.

Table 3 also shows that for TAX registration and TAX road, the differences across fuel types are relevant, which is an effect the pooled model cannot capture.

Table 12 Dependence of car emissions (aggregated over fuels) and diesel share on taxes

\begin{tabular}{|c|c|c|c|c|}
\hline \multirow[t]{2}{*}{ Dependent variable } & \multicolumn{4}{|c|}{$(\log ) \mathrm{CO}_{2}$ intensity overall } \\
\hline & (1) & (2) & (3) & (4) \\
\hline TAX registration (average) & 0.096 & 0.097 & 0.097 & 0.054 \\
\hline TAX registration (difference) & $0.192 *$ & $0.192 *$ & $0.196 *$ & 0.185 \\
\hline CO2TAX registration (average) & -0.131 & -0.130 & $-0.134 *$ & $-0.139 *$ \\
\hline CO2TAX registration (difference) & 0.003 & 0.003 & 0.004 & -0.011 \\
\hline TAX road (average) & 1.381 & 1.381 & 1.381 & 1.219 \\
\hline TAX road (difference) & $1.633 *$ & $1.638 *$ & $1.646^{*}$ & $1.631 *$ \\
\hline CO2TAX road (average) & $0.854 *$ & $0.853 *$ & $0.844^{*}$ & 0.703 \\
\hline CO2TAX road (difference) & 0.024 & 0.025 & 0.016 & 0.021 \\
\hline Fuel tax rate (average) & $-0.121 *$ & $-0.121 *$ & $-0.128^{*}$ & -0.090 \\
\hline Fuel tax rate (difference) & $0.127 *$ & $0.126^{*}$ & 0.134 & $0.166^{* *}$ \\
\hline$(\log )$ income & $0.158 * * *$ & 0.187 & $0.161 * * *$ & \\
\hline (log) income squared & & -0.001 & & \\
\hline Income & & & & $0.003 * *$ \\
\hline Unemployment & & & 0.0004 & \\
\hline Convergence & -0.029 & -0.029 & -0.029 & -0.035 \\
\hline Time FEs & Yes & Yes & Yes & Yes \\
\hline Country FEs & Yes & Yes & Yes & Yes \\
\hline Observations & 150 & 150 & 150 & 150 \\
\hline R-squared within & 0.501 & 0.501 & 0.502 & 0.479 \\
\hline R-squared & 0.974 & 0.974 & 0.974 & 0.973 \\
\hline TAX registration (joint) & $0.050 * *$ & $0.099 *$ & $0.019 * *$ & 0.130 \\
\hline CO2TAX registration (joint) & $0.000 * * *$ & $0.001 * * *$ & $0.000 * * *$ & $0.000 * * *$ \\
\hline TAX road (joint) & 0.146 & 0.177 & 0.153 & 0.161 \\
\hline CO2TAX road (joint) & 0.183 & 0.185 & 0.212 & 0.337 \\
\hline Fuel tax (joint) & $0.086^{*}$ & 0.112 & 0.150 & $0.088^{*}$ \\
\hline
\end{tabular}

Differences are computed as $\{$ diesel $\}-\{$ petrol $\}$. Significance: $* * * p<0.01 ; * * p<0.05 ; * p<0.1$. Observations are clustered by country. The R-squared within is calculated for the residuals after both time and country FEs. The bottom 5 rows report the $p$ values of the joint significance tests 


\section{Robustness with Respect to the Economic Recession}

To further explore whether our results may be driven by the recession, we perform additional sensitivity analysis. Table 12 presents the full model with all controls (except the transmission mechanisms), where we allow for (1) a quadratic relationship between $\mathrm{CO}_{2}$ intensity and $\log$ income, (2) unemployment to determine $\mathrm{CO}_{2}$ intensity in addition to log income, and (3) a relationship between $\mathrm{CO}_{2}$ intensity and the income level (in 1000 euros). The first column reproduces the result from Table 3 in the main text. Overall, we find that our results are robust to this alternative specification.

\section{Additional Figures and Tables}

See Tables 13, 14, 15 and Fig. 5.

Table 13 Constructed tax levels, 2001

\begin{tabular}{|c|c|c|c|c|c|c|c|c|}
\hline & \multicolumn{2}{|c|}{$\begin{array}{l}\text { Vehicle registration } \\
\text { tax rate }\end{array}$} & \multicolumn{2}{|c|}{$\begin{array}{l}\text { Vehicle registration } \\
\text { tax rate, } \mathrm{CO}_{2} \\
\text { sensitivity }\end{array}$} & \multicolumn{2}{|c|}{$\begin{array}{l}\text { Annual tax } \\
\text { rate }\end{array}$} & \multicolumn{2}{|c|}{$\begin{array}{l}\text { Annual tax } \\
\text { rate, } \mathrm{CO}_{2} \\
\text { sensitivity }\end{array}$} \\
\hline & Diesel & Petrol & Diesel & Petrol & Diesel & Petrol & Diesel & Petrol \\
\hline Austria & 0.31 & 0.26 & 0.10 & 0.10 & 0.051 & 0.079 & -0.068 & -0.087 \\
\hline Belgium & 0.20 & 0.19 & -0.03 & 0.00 & 0.024 & 0.015 & 0.003 & -0.002 \\
\hline Denmark & 1.12 & 0.98 & 0.30 & 0.43 & 0.038 & 0.034 & -0.012 & 0.023 \\
\hline Finland & 0.63 & 0.63 & 0.03 & 0.08 & 0.027 & 0.040 & -0.028 & -0.047 \\
\hline France & 0.19 & 0.18 & -0.02 & 0.00 & 0.000 & 0.000 & 0.000 & 0.000 \\
\hline Germany & 0.17 & 0.15 & -0.06 & 0.00 & 0.014 & 0.007 & -0.010 & -0.005 \\
\hline Greece & 0.57 & 0.33 & 0.66 & 0.33 & 0.009 & 0.011 & -0.019 & -0.002 \\
\hline Ireland & 0.49 & 0.44 & 0.11 & 0.11 & 0.025 & 0.025 & -0.001 & 0.001 \\
\hline Italy & 0.21 & 0.20 & -0.07 & -0.02 & 0.014 & 0.017 & -0.008 & -0.004 \\
\hline Luxembourg & 0.16 & 0.14 & -0.06 & 0.00 & 0.004 & 0.005 & -0.003 & -0.003 \\
\hline Netherlands & 0.47 & 0.40 & 0.12 & 0.13 & 0.064 & 0.040 & -0.040 & -0.009 \\
\hline Portugal & 0.47 & 0.43 & 0.03 & 0.23 & 0.002 & 0.003 & 0.002 & 0.001 \\
\hline Spain & 0.25 & 0.22 & -0.03 & 0.07 & 0.005 & 0.005 & -0.003 & -0.002 \\
\hline Sweden & 0.24 & 0.23 & -0.02 & 0.00 & 0.036 & 0.010 & -0.016 & -0.003 \\
\hline United Kingdom & 0.20 & 0.17 & -0.11 & -0.02 & 0.020 & 0.030 & -0.027 & -0.029 \\
\hline
\end{tabular}


Table 14 Constructed tax levels, 2010

\begin{tabular}{|c|c|c|c|c|c|c|c|c|}
\hline & \multicolumn{2}{|c|}{$\begin{array}{l}\text { Vehicle registration } \\
\text { tax rate }\end{array}$} & \multicolumn{2}{|c|}{$\begin{array}{l}\text { Vehicle registration } \\
\text { tax rate, } \mathrm{CO}_{2} \\
\text { sensitivity } \\
\end{array}$} & \multicolumn{2}{|c|}{$\begin{array}{l}\text { Annual tax } \\
\text { rate }\end{array}$} & \multicolumn{2}{|c|}{$\begin{array}{l}\text { Annual tax } \\
\text { rate, } \mathrm{CO}_{2} \\
\text { sensitivity } \\
\end{array}$} \\
\hline & Diesel & Petrol & Diesel & Petrol & Diesel & Petrol & Diesel & Petrol \\
\hline Austria & 0.27 & 0.24 & 0.16 & 0.16 & 0.025 & 0.028 & 0.000 & 0.005 \\
\hline Belgium & 0.20 & 0.19 & 0.02 & 0.01 & 0.015 & 0.015 & 0.006 & 0.008 \\
\hline Denmark & 1.00 & 0.89 & 0.25 & 0.53 & 0.025 & 0.024 & 0.010 & 0.024 \\
\hline Finland & 0.46 & 0.43 & 0.35 & 0.23 & 0.023 & 0.035 & -0.021 & -0.030 \\
\hline France & 0.19 & 0.19 & 0.03 & -0.02 & 0.000 & 0.000 & 0.001 & 0.000 \\
\hline Germany & 0.18 & 0.18 & 0.00 & 0.01 & 0.019 & 0.020 & -0.004 & -0.008 \\
\hline Greece & 0.40 & 0.30 & 0.16 & 0.25 & 0.020 & 0.013 & 0.001 & 0.015 \\
\hline Ireland & 0.42 & 0.39 & 0.32 & 0.22 & 0.014 & 0.021 & 0.033 & 0.043 \\
\hline Italy & 0.21 & 0.22 & -0.03 & -0.04 & 0.015 & 0.015 & 0.003 & 0.005 \\
\hline Luxembourg & 0.15 & 0.15 & -0.01 & -0.01 & 0.004 & 0.007 & 0.008 & 0.004 \\
\hline Netherlands & 0.46 & 0.38 & 0.26 & 0.26 & 0.068 & 0.038 & -0.021 & -0.008 \\
\hline Portugal & 0.48 & 0.35 & 0.35 & 0.22 & 0.010 & 0.011 & 0.005 & 0.001 \\
\hline Spain & 0.21 & 0.22 & 0.16 & 0.12 & 0.005 & 0.005 & 0.000 & -0.003 \\
\hline Sweden & 0.24 & 0.24 & 0.06 & 0.001 & 0.017 & 0.008 & 0.011 & 0.001 \\
\hline United Kingdom & 0.19 & 0.18 & -0.01 & -0.05 & 0.007 & 0.010 & 0.012 & 0.011 \\
\hline
\end{tabular}

Table 15 Correlation between fiscal vehicle measures

\begin{tabular}{|c|c|c|c|c|c|c|c|c|}
\hline \multicolumn{4}{|c|}{ Registration } & \multicolumn{4}{|c|}{ Annual } & Fuel \\
\hline Petrol & & Diesel & & Petrol & & Diesel & & Petrol \\
\hline Level & $\mathrm{CO}_{2}$ & Level & $\mathrm{CO}_{2}$ & Level & $\mathrm{CO}_{2}$ & Level & $\mathrm{CO}_{2}$ & \\
\hline
\end{tabular}

\section{Registration}

Petrol

$\begin{array}{lrr}\text { Level } & 1.00 \\ \mathrm{CO}_{2} & -0.38 & 1.00\end{array}$

Diesel

$\begin{array}{lrrrr}\text { Level } & \mathbf{0 . 6 7} & -0.16 & 1.00 & \\ \mathrm{CO}_{2} & -0.21 & \mathbf{0 . 6 1} & 0.24 & 1.00\end{array}$

Annual

Petrol

$\begin{array}{lrrrrrr}\text { Level } & 0.06 & -0.09 & 0.13 & -0.07 & 1.00 & \\ \mathrm{CO}_{2} & -0.06 & 0.11 & -0.13 & 0.12 & -\mathbf{0 . 9 0} & 1.00\end{array}$

Diesel

$\begin{array}{lrrrrrrrr}\text { Level } & 0.00 & -0.09 & 0.08 & -0.11 & \mathbf{0 . 8 5} & -\mathbf{0 . 7 5} & 1.00 & \\ \mathrm{CO}_{2} & 0.08 & 0.13 & 0.02 & 0.18 & \mathbf{- 0 . 7 6} & \mathbf{0 . 8 4} & \mathbf{- 0 . 7 6} & 1.00\end{array}$

Fuel

$\begin{array}{lrrrrrrrrrr}\text { Petrol } & -0.03 & 0.09 & -0.04 & 0.01 & 0.05 & -0.04 & 0.04 & -0.11 & 1.00 & \\ \text { Diesel } & -0.03 & 0.10 & 0.03 & 0.07 & 0.14 & -0.04 & 0.15 & -0.09 & \mathbf{0 . 7 5} & 1.00\end{array}$

Correlations for variables after taking out time and country fixed effects. In bold those $>0.5$. Annual taxes are multi-collinear 


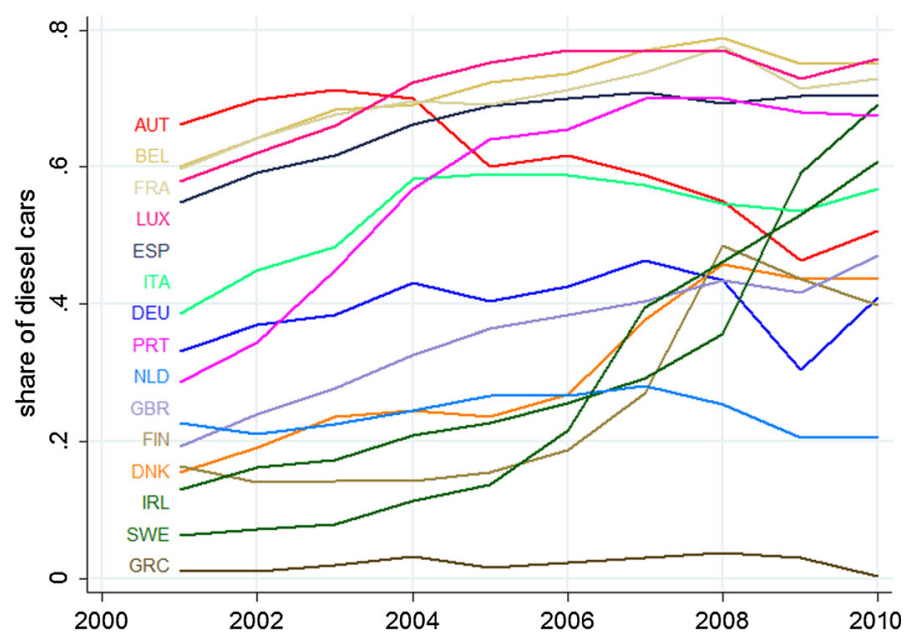

Fig. 5 Share of diesel cars in new fleet. Source: Campestrini and Mock (2011)

\section{References}

ACEA European Automobile Manufacturers Association (2010) ACEA tax guide, 2001-2010 edition, Brussels Achtnicht M (2012) German car buyers' willingness to pay to reduce $\mathrm{CO}_{2}$ emissions. Clim Change 113:679697

Allcott H, Wozny N (2014) Gasoline prices, fuel economy, and the energy paradox. Rev Econ Stat 96(5):779795

Anderson SP, de Palma A, Kreider B (2001) Tax incidence in differentiated product oligopoly. J Public Econ 81(2):173-192

Berry S, Levinsohn J, Pakes A (1995) Automobile prices in equilibrium. Econometrica 63(4):841-890

Binswanger M (2001) Technological progress and sustainable development: what about the rebound effect? Ecol Econ 36:119-132

Blanco G, Gerlagh R, Suh S et al (2014) Drivers, trends and mitigation. In: Edenhofer O, Pichs-Madruga R, Sokona Y et al (eds) Climate Change 2014: mitigation of climate change. Contribution of Working Group III to the Fifth Assessment Report of the Intergovernmental Panel on Climate Change. Cambridge University Press, Cambridge

Bordley RF (1993) Estimating automotive elasticities from segment elasticities and first choice/second choice data. Rev Econ Stat 74(3):455-462

Brand C, Anable J, Tran M (2013) Accelerating the transformation to a low carbon passenger transport system. The role of car purchase taxes, feebates, road taxes and scrappage incentives in the UK. Transp Res Part A Policy Pract 49:132-148

Brookes L (2000) Energy efficiency fallacies revisited. Energy Policy 28:355-367

Burke PJ (2014) Green pricing in the Asia Pacific: an idea whose time has come? Asia Pac Policy Stud 1:561-575

Burke PJ, Nishitateno S (2013) Gasoline prices, gasoline consumption, and new-vehicle fuel economy: evidence for a large sample of countries. Energy Econ 36:363-370

Busse MR, Knittel CR, Zettelmeyer F (2013) Are consumers myopic? Evidence from new and used car purchases. Am Econ Rev 103(1):220-256

Campestrini M, Mock P (2011) European vehicle market statistics. ICCT, Washington

Chugh R, Cropper ML (2014) The welfare effects of fuel conservation policies in the Indian car market. Working Paper 20460, National Bureau of Economic Research

Ciccone A (2015) Environmental effects of a vehicle tax reform: empirical evidence from Norway. Memorandum, Department of Economics, University of Oslo 03/2015

Copenhagen Economics (2010) Company car taxation. Working paper 22, Copenhagen 
Davis LW, Kilian L (2011) Estimating the effect of a gasoline tax on carbon emissions. J Appl Econom 16:1187-1214

DellaVigna S (2009) Psychology and economics. Evidence from the field. J Econ Lit 47(2):315-372

D'Haultfoeuille X, Givord P, Boutinx X (2014) The environmental effect of green taxation: the case of the French "Bonus/Malus". Econ J 124(578):444-480

Dvir E, Strasser G (2014) Does marketing widen borders? Cross-country price dispersion in the European car market. Boston College working papers in economics 831

European Commission (2005) Proposal for a council directive on passenger car related taxes. COM (2005) 261 final, Brussels

European Commission (2011a) Price car reports. http://ec.europa.eu/competition/sectors/motor_vehicles/ prices/archive.html

European Commission (2011b) Roadmap to a single European transport area-towards a competitive and resource efficient transport system. COM(2011) 144 final, Brussels

European Commission (2016) Reducing $\mathrm{CO}_{2}$ emissions from passenger cars. http://ec.europa.eu/clima/ policies/transport/vehicles/cars

European Parliament and Council (1999) Directive 1999/94/EC of the European Parliament and of the Council of 13 December 1999 relating to the availability of consumer information on fuel economy and $\mathrm{CO}_{2}$ emissions in respect of the marketing of new passenger cars, Brussels

European Parliament and Council (2004) Directive 2004/35/EC of the European Parliament and of the Council of 21 April 2004 on environmental liability with regard to the prevention and remedying of environmental damage, Brussels

European Parliament and Council (2009) Regulation No. 443/2009 of 23 April 2009 setting emission performance standards for new passenger cars as part of the community's integrated approach to reduce $\mathrm{CO}_{2}$ emissions from light-duty vehicles, Brussels

Eurostat (2014) GDP and main components—volumes (nama_gdp_k). Available at http://epp.eurostat.ec. europa.eu/portal/page/portal/national_accounts/data/database

Finkelstein A (2009) E-Ztax: tax salience and tax rates. Q J Econ 124(3):969-1010

Fontaras G, Samars Z (2010) On the way to $130 \mathrm{gCO}_{2} / \mathrm{km}$-Estimating the future characteristics of the average European passenger car. Energy Policy 38:1826-1833

Frondel M, Vance C (2014) Fuel taxes versus efficiency standards: an instrumental variable approach. Ruhr Economic Paper 445

Gallagher KS, Muehlegger EJ (2011) Giving green to get green. Incentives and consumer adoption of hybrid vehicle technology. J Environ Econ Manag 61:1-15

Gayer T (2004) The fatality risks of sport-utility vehicles, vans, and pickups relative to cars. J. Risk Uncertain 28:103-133

Gbegbaje-Das E (2013) Life cycle $\mathrm{CO}_{2}$ e assessment of low carbon cars 2020-2030. PE International, London

Goodwin P, Dargay J, Hanly M (2004) Elasticities of road traffic and fuel consumption with respect to price and income: a review. Trans Rev 24(3):275-292

Greene D, Patterson P, Sing M, Li J (2005) Feebates, rebates and gas-guzzler taxes: a study of incentives for increased fuel economy. Energy Policy 33:757-775

Greene D, Evans DH, Hiestand J (2013) Survey evidence on the willingness of U.S. consumers to pay for automotive fuel economy. Energy Policy 61:1539-1550

Grigolon L, Leheyda N, Verboven F (2016) Scrapping subsidies during the financial crisis - evidence from Europe. Int J Ind Org 44:41-59

Gutierrez-i-Puigarnau E, van Ommeren JN (2011) Welfare effects of distortionary fringe benefits taxation: the case of employer-provided cars. Int Econ Rev 52(4):1105-1122

Hausberger S (2006) Fuel consumption and emissions of modern passenger cars. Institute for Internal Combustion Engines and Thermodynamics, Report no. I-25/10 Haus-Em 07/10/676, Graz

Heffetz O (2011) A test of conspicuous consumption: visibility and income elasticities. Rev Econ Stat 93(4):1101-1117

Hennessy H, Tol RS (2011) The impact of tax reform on new car purchases in Ireland. Energy Policy 39:70597067

Hoen A, Geilenkirchen GP (2006) De waarde van een SUV - waarom de gemiddelde auto in Nederland niet zuiniger wordt. Bijdrage aan het Colloquium Vervoersplanologisch Speurwerk 2006, 23 en 24 november 2006, Amsterdam

Huse C, Lucinda C (2013) The market impact and the cost of environmental policy: evidence from the Swedish green car rebate. Econ J 124:393-419

Khazzoom JD (1980) Economic implications of mandated efficiency standards for household appliances. Energy J 1:21-40 
Kilian L, Sims E (2006) The effects of real gasoline prices on automobile demand: a structural analysis using micro data. Working paper, University of Michigan, Ann Arbor

Klier T, Linn J (2013) Fuel prices and new vehicle fuel economy-comparing the United States and Western Europe. JEEM 66:280-300

Klier T, Linn J (2015) Using vehicle taxes to reduce carbon dioxide emissions rates of new passenger vehicles: evidence from France, Germany, and Sweden. Am Econ J Econ Policy 7:212-242

Köhler F (2013) Testing of particulate emissions from positive ignition vehicles with direct fuel injection system. Technical report, 2013-09-26, TûV Nord

Kok R (2013) New car preferences move away from greater size, weight and power: impact of Dutch consumer choices on average $\mathrm{CO}_{2}$-emissions. Transp Res Part D Transp Environ 21:53-61

Konishi Y, Meng Z (2014) Can green car taxes restore efficiency? Evidence from the Japanese new car market. Tokyo Center for Economic Research working paper E-82

Leinert S, Daly H, Hyde B, Gallachóir BÓ (2013) Co-benefits? Not always: Quantifying the negative effect of a $\mathrm{CO}_{2}$-reducing car taxation policy on NOx emissions. Energy Policy 63:1151-1159

Ligterink NE, Bos B (2010) CO2 uitstoot van personenwagens in norm en praktijk -analyse van gegevens van zakelijke rijders. TNO report MON-RPT- 2010-0014, Delft

Ligterink NE, Eijk ARA (2014) Update of real-world fuel consumption of business passenger cars based on Travelcard Nederland fuelpass data. TNO Report 2014 R11063

Mabit SL (2014) Vehicle type choice under the influence of a tax reform and rising fuel prices. Transp Res Part A 64(2014):32-42

Mannering F, Winston C (1985) A dynamic empirical analysis of household vehicle ownership and utilization. RAND J Econ 16(2):215-236

Mock P, German J, Bandivadekar A, Riemersma I (2012) Discrepancies between type-approval and "realworld" fuel-consumption and $\mathrm{CO}_{2}$ values. Assessment for 2001-2011 European passenger cars, ICCT working paper $2012-2$

Mock P, Tietge U, Franco V, German J, Bandivadekar A, Ligterink N, Lambrecht U, Kühlwein J, Riemersma I (2014) From laboratory to road: a 2014 update of official and "real-world" fuel consumption and CO2 values for passenger cars in Europe. International Council on Clean Transportation Europe, Berlin

Nijland H, Mayeres I, Manders T, Michiels H, Koetse M, Gerlagh R (2012) Use and effectiveness of economic instruments in the decarbonisation of passenger cars. ETC-ACM technical paper 2012/11, Bilthoven

Rogan F, Dennehy E, Daly H, Howley M, Gallachóir BPÓ (2011) Impacts of an emission based private car taxation policy. First year ex-post analysis. Transp Res Part A Policy Pract 45:583-597

Ryan L, Ferreira S, Convery F (2009) The impact of fiscal and other measures on new passenger car sales and $\mathrm{CO}_{2}$ emissions intensity: evidence from Europe. Energy Econ 31:365-374

Sims R, Schaeffer R et al (2014) Transport. In: Edenhofer O, Pichs-Madruga R, Sokona Y et al (eds) Climate Change 2014: mitigation of climate change. Contribution of Working Group III to the Fifth Assessment Report of the Intergovernmental Panel on Climate Change. Cambridge University Press, Cambridge

Sorrell S, Dimitroupolos J (2008) The rebound effect: microeconomic definitions, limitations and extensions. Ecol Econ 65(3):636-649

van Essen et al (2012) An inventory of measures for internalising external costs in transport. http://ec.europa. eu/transport/themes/sustainable/studies/sustainable_en.htm

van Meerkerk J, Renes G, Ridder G (2014) Greening the Dutch car fleet: the role of differentiated sales taxes. PBL working paper 18, PBL, Den Haag

Vonk WA, Verbeek RP (2010) Verkennende metingen van schadelijke uitlaatgasemissies van personenvoertuigen met euro6-dieseltechnologie, TNO-rapport MON-RPT-2010-02278, Delft

White MJ (2004) The "arms race" on American roads: the effect of sport utility vehicles and pickup trucks on traffic safety. J Law Econ 47:333-355 